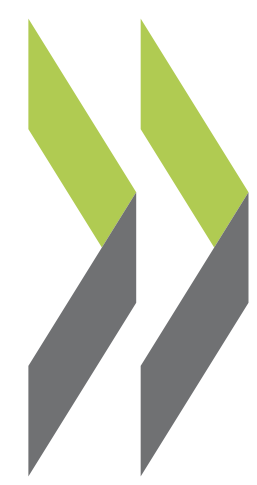

OECD Economics Department Working Papers No. 320

\title{
Enhancing Expenditure Control with a Decentralised Public Sector in Denmark
} Steen Daugaard 
ENHANCING EXPENDITURE CONTROL WITH A DECENTRALISED PUBLIC SECTOR IN DENMARK

ECONOMICS DEPARTMENT WORKING PAPERS No. 320

by

Steen Daugaard

All Economics Department Working Papers are now available through OECD's Internet Web site at http://www.oecd.org/eco 


\section{ABSTRACT/RÉSUMÉ}

\section{Enhancing Expenditure Control with a Decentralised Public Sector in Denmark}

This paper analyses of some the key aspects of public expenditure policy in Denmark. The public expenditure to GDP ratio has abated markedly since the mid-1990s, reflecting both cyclical gains and the return on structural reforms. Nevertheless, the underlying upward pressure on government spending, notably from the demand for personal services, is generally perceived to be significant and expected to persist. The origins of such pressure, as well as means of containing it in the future, are discussed. With public consumption being very high by international standards, the paper advocates greater competition in the provision of services to individuals and more reliance on market signals such as client choice and user charges to enhance the efficiency of resource allocation. A particular feature of the Danish public sector is the fact that counties and municipalities have been assigned a wider range of responsibilities than in any other OECD country as well as extensive taxing powers. The unplanned upward drift in local governments' spending levels and tax rates, notably in the second half of the 1990s, indicate that reforms of the framework for managing local governments may be needed.

JEL classification: E62, H11, H42, H50, H51, H52, H53, H77

Keywords: Denmark, expenditure policy, inter-governmental relations

\section{Renforcer le contrôle des dépenses dans un secteur public décentralisé au Danemark}

Ce document analyse quelques-uns des aspects les plus importants de la politique des dépenses publiques au Danemark. Le rapport des dépenses publiques au PIB a diminué de façon significative depuis le milieu des années 1990, traduisant aussi bien des gains conjoncturels que des retombées positives des réformes structurelles. Néanmoins, la croissante pression sous-jacente sur les dépenses gouvernementales, en particulier du fait de la demande de services personnels, est généralement perçue comme significative et devant se maintenir. Le document aborde les origines de cette pression ainsi que les moyens pour la contenir dans l'avenir. Étant donné le niveau élevé de la consommation publique par rapport à la plupart des autres pays, il défend la nécessité d'une plus grande concurrence au niveau de la fourniture des services personnels et d'un recours plus important aux signaux du marché, tels que le choix des clients et les dépenses des utilisateurs, afin d'accroître l'efficacité de l'allocation de ressources. Une des particularités du secteur public danois consiste dans le fait que les contés et les municipalités se voient attribuer une part de responsabilité plus large et un pouvoir fiscal plus important que dans tout autre pays de l'OCDE. La dérive à la hausse des dépenses et des taux d'imposition de la part des autorités locales, notamment au cours de la deuxième moitié des années 1990, constitue une indication que des réformes au niveau structurel de la gestion publique locale pourraient s'avérer nécessaires.

Classification JEL : E62, H11, H42, H50, H51, H52, H53, H77

Mots clés : Danemark, politique des dépenses publiques, relations intergouvernementales

\section{Copyright () OECD 2002. All rights reserved.}

Applications for permission to reproduce or translate all, or part of, this material should be made to: Head of Publications Service, OECD, 2 rue André-Pascal, 75775 PARIS CEDEX 16, France 


\section{TABLE OF CONTENTS}

Enhancing expenditure control with a decentralised public sector in Denmark ..............................5

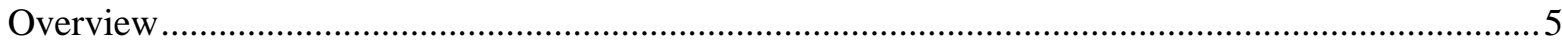

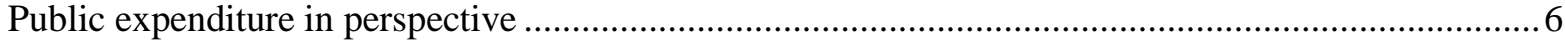

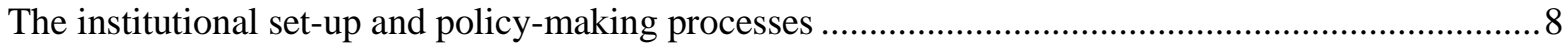

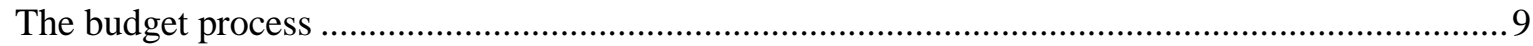

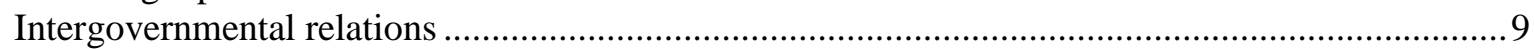

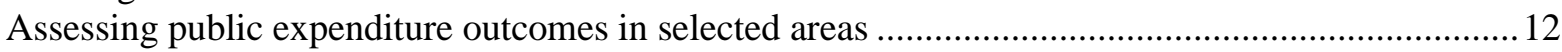

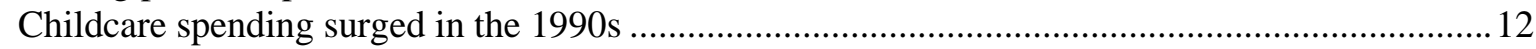

Elderly care would benefit from introducing demand signals consistently ....................................14

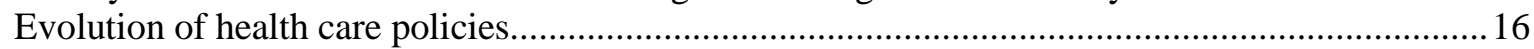

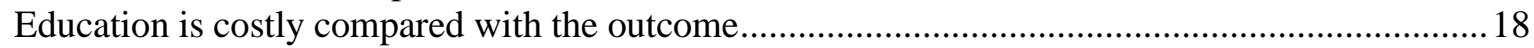

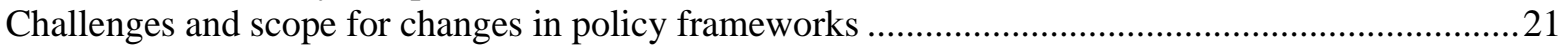

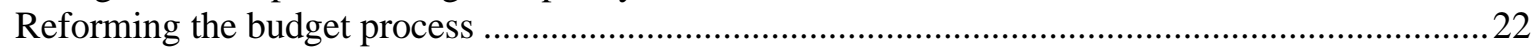

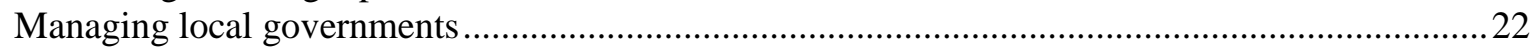

Encouraging competition and extending market signals .............................................................2

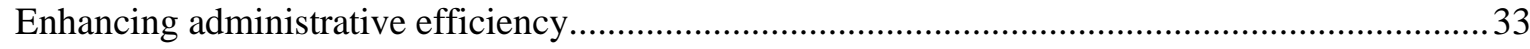

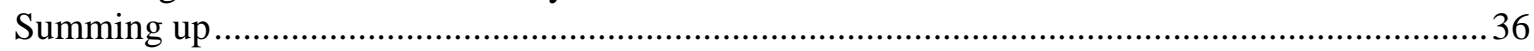

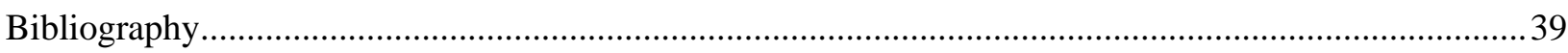

Annexes

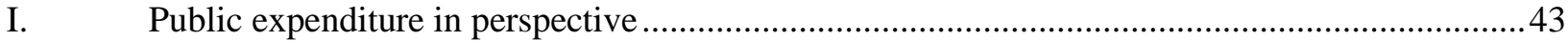

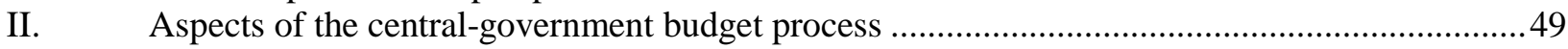

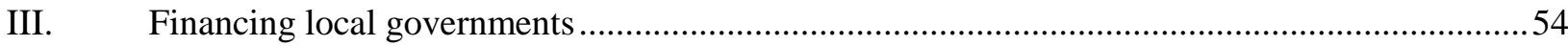

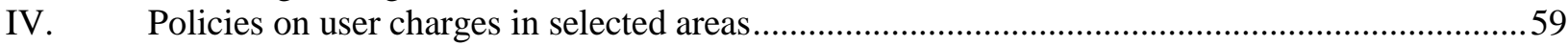

\section{Boxes}

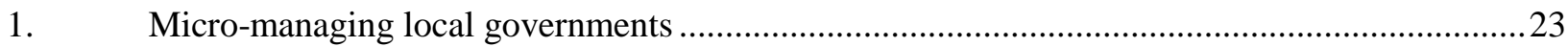

2. Distributional effects of user and tax financing of additional spending .................................... 30

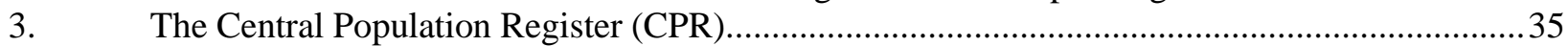

\section{Tables}

1. Local governments' taxing powers in selected OECD countries, 1995 ....................................11

2. Out-of-home childcare in selected European countries, 1996 ..............................................14

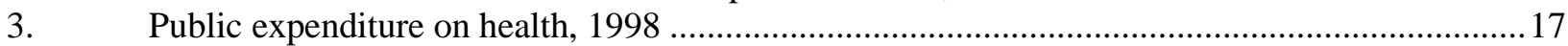

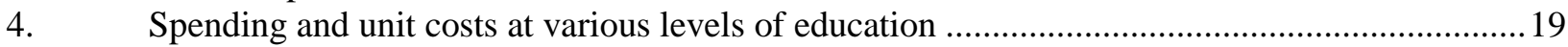

5. Local governments' purchases of external services, 1991-99 ….............................................28

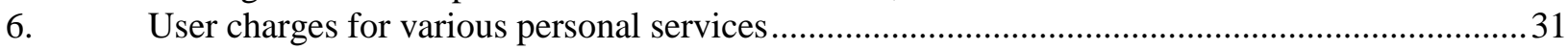

7. The prevalence of performance-related contracts in the central government .............................34

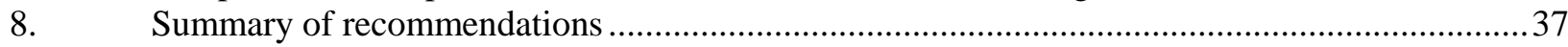


Annexes

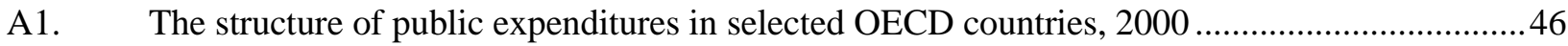

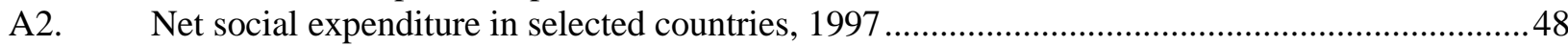

A3. Main features and characteristics of the budget process ...............................................50

A4. The responsibilities of counties and municipalities .......................................................5

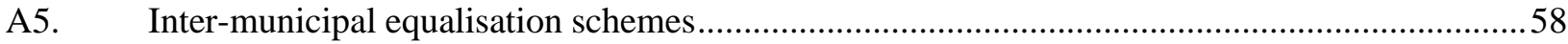

\section{Figures}

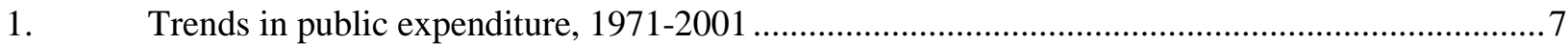

2. Public consumption in selected OECD countries ........................................................... 8

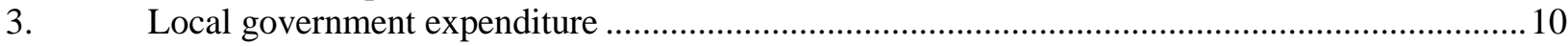

4. Public consumption on education, health and social services and female13

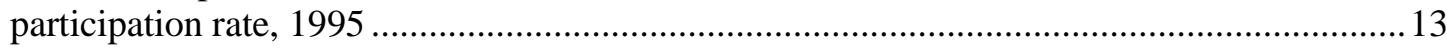

5. Full-time staff of home help and residents in institutional care .......................................15

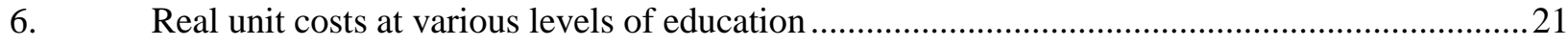

7. Planned and actual income-tax rate increases by local governments ..................................25

Annexes

A1. Relative price and cost developments in the public sector ............................................45

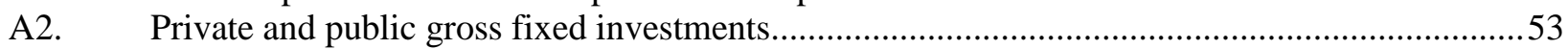

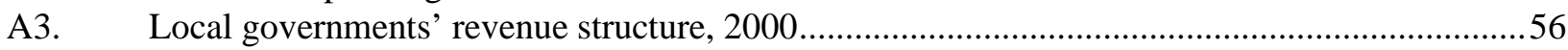

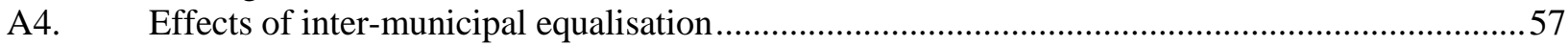


ECO/WKP(2002)6

\title{
ENHANCING EXPENDITURE CONTROL WITH A DECENTRALISED
}

\section{PUBLIC SECTOR IN DENMARK}

\author{
by Steen Daugaard ${ }^{1}$
}

\section{Overview}

1. A central feature of the Scandinavian welfare state such as Denmark's is its fine-mesh social-security safety net and the provision of a broad range of free or almost free public services. Such a system almost inevitably implies a high level of public outlays and considerable redistribution of income and consumption. The analysis of Danish expenditure policies in this paper takes as a point of departure that the current system enjoys broad support, at least in its fundamental design. Nonetheless, an assessment of expenditure policies cannot escape dealing with issues seen by many as basic features of the welfare state. However, the principal issue faced here is not whether the level of public spending is appropriate, but whether adequate policies are in place to encourage a high level of efficiency and ensure overall spending control.

2. The paper itself focuses on the key policy issues, whereas most factual background information is provided in subsequent annexes. However, the analysis starts out by describing the level and structure of current public expenditure in a historical and cross-country context. The higher level of total expenditure in Denmark than in most other EU countries is partially attributable to technical factors, notably the higher taxation of income transfers in Denmark. However, public consumption constitutes a larger proportion of GDP than in any other OECD country except Sweden, and the scope of redistribution through public finances is greater than elsewhere. Next, the existing institutional settings and policy processes are described, and considerable attention is devoted to intergovernmental relations. These are particularly important in the Danish context, inasmuch as local governments - counties and municipalities - have been assigned greater responsibilities and taxing powers than in almost any other OECD country.

3. A number of factors may combine to put upward pressure on public spending and to challenge the extensive reliance on tax financing in the future. On the revenue side, these would comprise most

1. The author is an economist at the OECD. This paper was originally produced for the OECD Economic Survey of Denmark published in January 2002 under the authority of the Economic and Development Review Committee. The author is indebted to colleagues in the Economics Department of the OECD for comments and drafting suggestions, in particular Peter Jarrett, Mike Feiner, Jørgen Elmeskov, Andrew Dean, Isabelle Joumard and Deborah Roseveare. Special thanks go to Raoul de Saint Preux and to Mee-Lan Frank for technical assistance. 
importantly a continued downward drift in average working hours and a demographically induced contraction of labour supply, thereby reducing the income and expenditure tax base. On the expenditure side, the prospective rise in the old-age dependency ratio will also put upward pressure on public spending. Furthermore, the relative costs of public-sector production are likely to trend upwards, because such production is necessarily more labour intensive than its private sector counterpart (due to the so-called "Baumol disease"). An increase in relative costs could be further reinforced if the already mounting evidence of shortages of skilled labour in the public sector prompts an increase in relative wages. Finally, depending primarily on the income elasticity of demand, pressures for higher-standard services and increased coverage may prove to be considerable in many areas.

4. The possible quantitative significance of these pressures, let alone their timing, is difficult to assess with any accuracy, and offsetting factors may mitigate them. Nonetheless, it is reasonably safe to assume that, overall, they will slowly but steadily strain public finances. Policy measures that aim at restraining public expenditure or enhancing the efficiency of provision and administration are warranted in their own right, but they will be even more important if the underlying upward pressure on public outlays proves to be significant. Among the policy issues raised in the following sections, the two most important are reforming the framework for managing local governments and moving towards a greater reliance on competition and market signals in the provision of public services. A more consistent use of contracting out, user charges and client choice could promote greater efficiency and help contain existing and future expenditure pressures. Considering the current sound stance of public finances, failing to deal with these challenges will not risk prompting an imminent fiscal imbalance. However, to safeguard the favourable starting point and facilitate better outcomes in terms of value for money, they nonetheless deserve attention sooner rather than later.

\section{Public expenditure in perspective}

5. Real public consumption has risen relatively rapidly over the past six to eight years. This has not been driven by demographic factors but reflects considerable increases in standards and coverage rates of public services (OECD, 2000). The fastest-growing areas have been secondary health care, pharmaceuticals, education and childcare (Finansministeriet, 2001). Nonetheless, the overall expenditure-to-GDP ratio declined significantly over the second half of the 1990s (Figure 1), as a result of dwindling transfer payments and interest outlays, the latter caused by a declining debt ratios and lower interest rates. Finally, according to the national accounts, wages have risen less than in the private sector and the deflator for non-wage public consumption has increased less than the GDP deflator (Annex I). ${ }^{2}$ To the extent that this reflects a temporary favourable development in relative prices and costs in the public sector, the lower potential for productivity increases in the provision of labour-intensive public services could cause the deflator for public consumption to increase faster than the GDP deflator in the future.

6. At 50 per cent, Denmark's public-expenditure-to-GDP ratio was 6 percentage points higher than the EU average in 2000 and 12 percentage points higher than the average level in the OECD area as a whole. However, accounting for the taxation of public transfers narrows these differences. Nevertheless, public consumption is higher than in any other OECD country except Sweden; at 25 per cent in 2000 its share of GDP was some 10 percentage points higher than in Ireland, the United States and Japan, while it was six percentage points above the EU average, a figure that has been fairly stable over the most recent decade (Figure 2). In contrast, social security outlays (transfer payments) are lower in Denmark than in a number of other EU countries once adjusted for the tax treatment (see Annex I for a further discussion). In

2. Davidsen and Hanus (2001) gives a detailed account of the evolution in the public consumption deflator from 1992 to 2000. According to their analysis, methodological weaknesses and shifts in the national accounts have tended to underestimate price increases and overestimate volume increases over this period. 
particular, public pension outlays are relatively small in Denmark, reflecting their predominantly flat rate and means-tested nature. In contrast, the earnings-related elements, which are a feature of the public pension systems of most countries, are almost entirely organised in private pension funds in Denmark. At some 90 per cent of GDP, private pension funds are bigger in Denmark than in most other countries. The relatively low level of net social transfers outlays also reflects the high labour force participation rate and the below-average unemployment rate. While the level is fairly modest compared with the EU average, the Danish transfer system tends to involve more redistribution than those of other countries. This is due to the fact that whereas most EU countries' transfer systems link contributions and benefits to individuals' earnings, the Danish system is predominantly a flat rate system with significant elements of means testing.

Figure 1. Trends in public expenditure, 1971-2001 Per cent of GDP
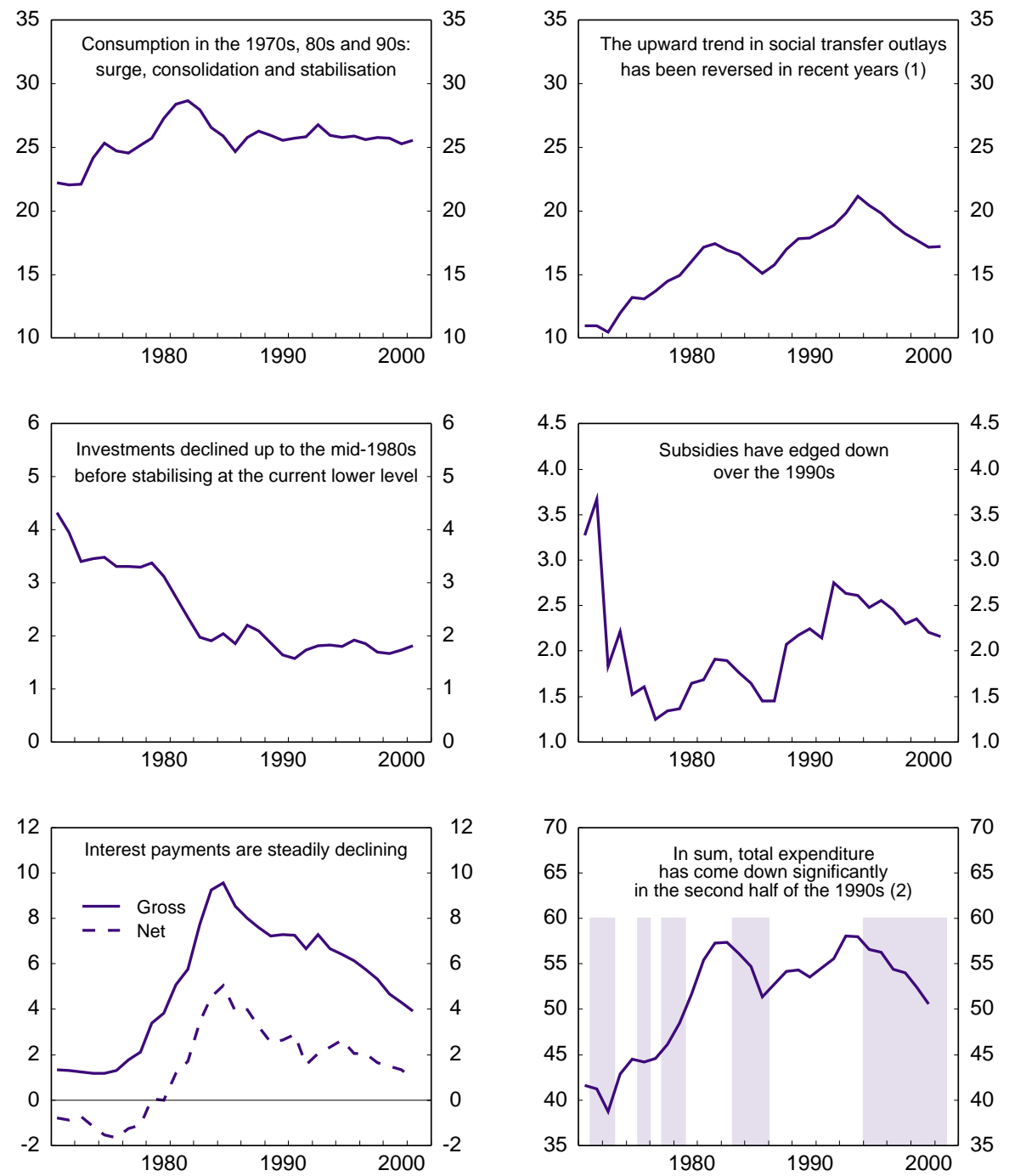

1. Pensions and social assistance benefits were increased but made taxable as from 1994 with little impact on net transfers. This implied a 1.9 percentage-point increase in the transfers-to-GDP ratio.

2. The shaded areas designate years of economic recovery as represented by an increasing employment rate. Source: Statistics Denmark; OECD. 
Figure 2. Public consumption in selected OECD countries Per cent of GDP
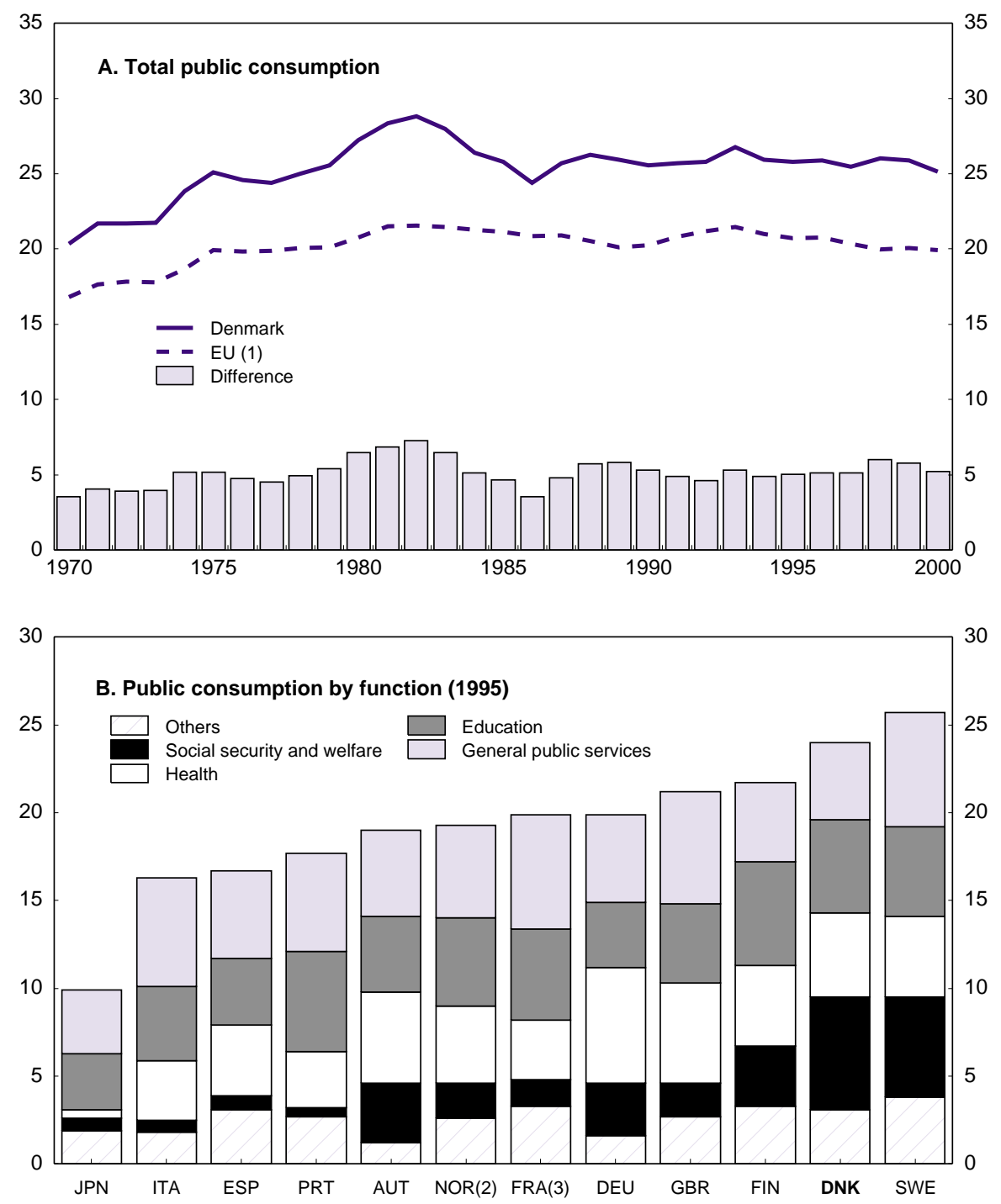

1. Excluding Luxembourg and Greece.

2. 1991.

3. 1993.

Source: OECD.

\section{The institutional set-up and policy-making processes}

7. Two particular features underpin the way expenditure policies are formed in Denmark. The first is the fact that coalition minority governments are the norm. The second is the extensive division of labour between the state (i.e. central government), counties and municipalities. Both of these elements contribute to a distinctly co-operative political climate. This section highlights the main features of the institutional settings that frame expenditure policies, while Annex II provides additional information. 


\section{The budget process}

8. The budget cycle is determined mainly by the deadlines specified in the constitution. The budget proposal is prepared by the government between January and June and presented to the parliament in late August. Discussions with opposition parties designed to build majority support for the budget usually take place in October/November. As in other countries, the adoption of the budget is also a vote of confidence. This creates a momentum for policy-making that, in the Danish tradition of coalition minority governments, is not present during the rest of the year. The August budget proposal should be seen not only as a statement of the government's priorities, but also to some extent as the strategic starting point for the subsequent political discussions, in which "new" topics may be raised by the government or opposition parties. Some of the measures required to finance new initiatives are not necessarily detailed in the budget proposal but may appear as unspecified savings or revenues to be decided upon during the negotiations. Likewise, measures may occasionally be included in the budget proposal mainly for tactical reasons and which the government is willing to "trade away". In addition, structural policy issues, which may have only limited consequences for next year's budget, are often brought up in the budget negotiation process, rather than being launched as separate discussions during the rest of the parliamentary session. ${ }^{3}$

9. While the budget proposal may not always be complete in stating the government's policy intentions it does serve an important purpose in specifying the government's intended overall fiscal stance. Although the fiscal stance in the final agreement may deviate from the budget proposal, such deviations have most often been relatively small. The specific fiscal stance measure on which the negotiations focus may vary from year to year depending primarily upon what the government considers a suitable target at the time. Since the early 1990s the so-called "fiscal effect" has become a key indicator along with the overall budget figures and indicators of the long-term sustainability of public finances taking into account the ageing of the population. The fiscal effect is based on model simulation, it measures the imputed first-year impact on GDP of discretionary fiscal policy initiatives, whether on the expenditure or the revenue side of the budget. In contrast the political commitment to keep a lid on total spending was stronger during most of the 1980s and nominal ceilings for total, non-cyclical, central-government outlays occupied a more central role in the process. In this sense, the focus in the budget process has shifted considerably from restraining total expenditures in the $1980 \mathrm{~s}$ to a more pragmatic, macroeconomic-management approach since the mid-1990s. In this regime, slippage on the expenditure side relative to the budget proposal has frequently been tolerated if it is compensated by additional revenue so that the fiscal-effect target has been achieved. The "tax freeze" that was recently declared by the government is likely to imply a significant change to this approach to fiscal policy making. Thus, with the "tax freeze", greater attention is needed throughout the budget process to keep spending within the originally set target, as any slippage would otherwise weaken the budget balance.

\section{Intergovernmental relations}

10. The government and parliament have devolved a very wide range of responsibilities to local governments (i.e. counties and municipalities). Annex III provides information on the main responsibilities of these lower levels of government as well as on their revenue structure. Local governments provide the lion's share of public-sector services and account for 70 per cent of total public consumption (Figure 3). The extensive reliance on local governments in the conduct of public-sector activities is clearly evident in an international comparison of local-government outlays relative to GDP and to total government expenditure. Denmark is second to none on both these measures. Local-government spending was 30 per

3. Recent examples of structural reforms that were presented only during the political process include the labour market reforms in 1995 and 1998, the reform of the early retirement benefit scheme in 1998, the abolition of the wealth tax in 1995 and the adult education reform in 1999. 
Figure 3. Local government expenditure

Per cent
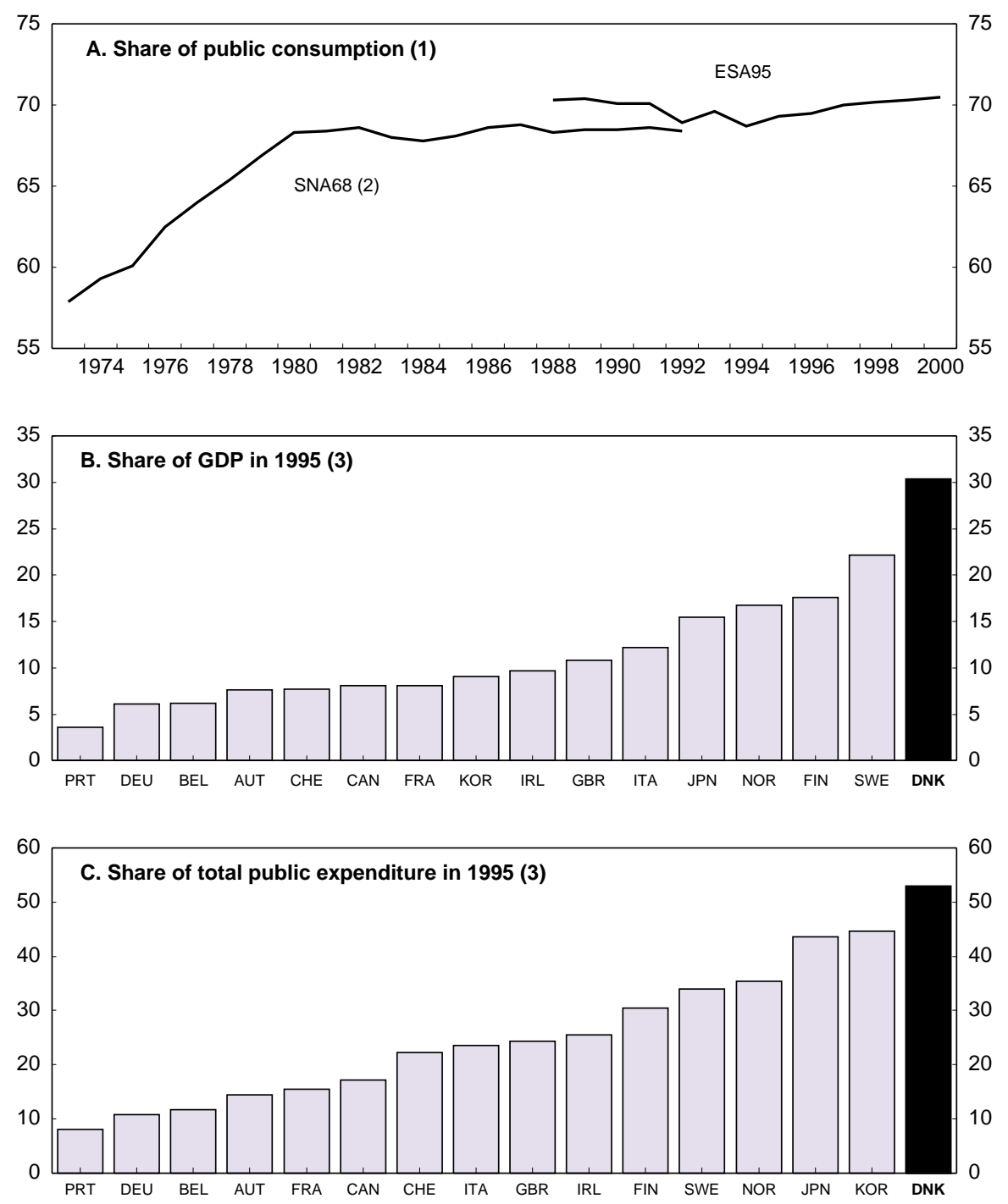

1. Consumption by local governments as a percentage of total public consumption.

2. Data for 1977 to 1979 are interpolated.

3. The figures do not include spending by state and provincial governments in federal countries.

Source: OECD, National Accounts.

cent of GDP in $1995,{ }^{4}$ followed by Sweden at 22 per cent, and Norway and Finland at 16 to 18 per cent. In other countries, local-government spending (excluding spending at the state level in federal countries) is often below 10 per cent of GDP. While (ad hoc) decisions have also played a part, the decentralisation strategy has been based on a blend of pragmatic political arguments, such as the strengthening of local democracy, and efficiency considerations. There has been broad consensus that central governing of local

4. More recent comparable information is not yet available due to the change of national accounts standards. 
service provision is inferior to local governing both in administrative efficiency and in targeting services at the right people. Danish counties and municipalities have also been assigned taxing powers that are possibly greater than in any other OECD country with the exception of Sweden (Table 1). The share of own revenues in financing local governments' expenditure is around 80 per cent, with taxes making up almost 60 per cent. The right to set income tax rates is widely seen as the cornerstone of local government autonomy, although it is not considered a constitutional right as it is in Sweden. ${ }^{5}$

Table 1. Local governments' taxing powers in selected OECD countries, 1995 $^{1}$

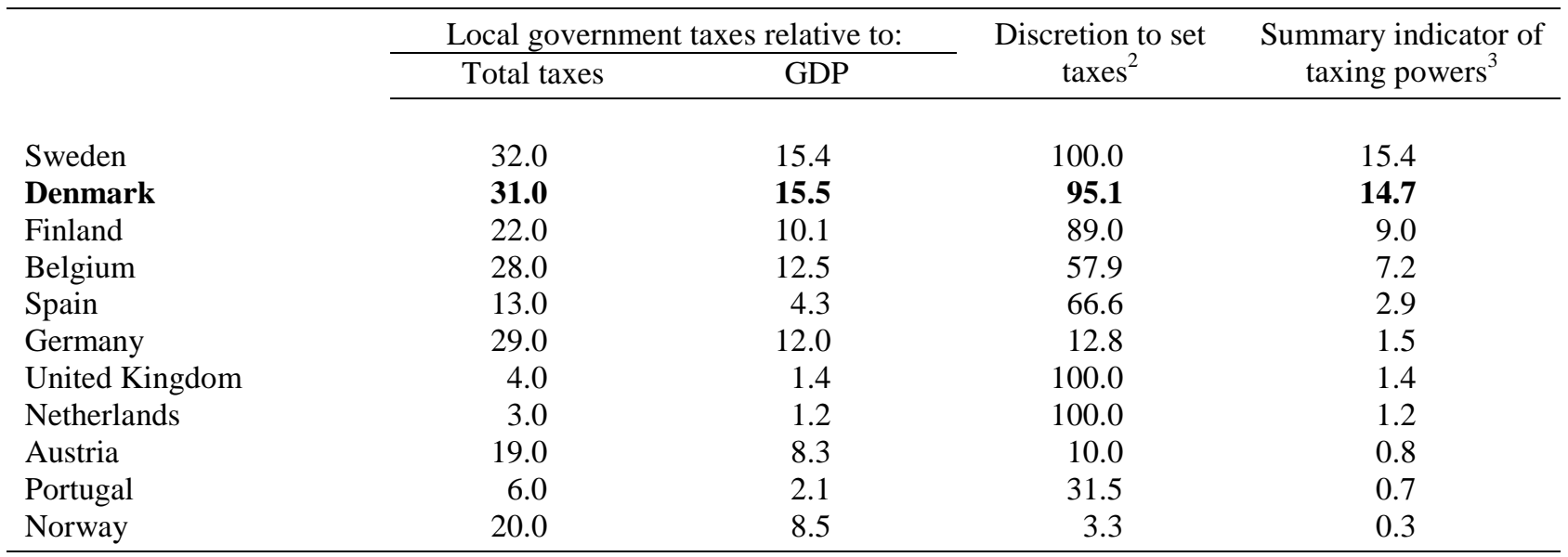

1. The countries are ranked in descending order according to the value of the summary indicator of taxing powers.

2. The figures show the percentage of their total taxes for which local governments hold full discretion over the tax rate or both the tax rate and the tax base. A value of 100 designates full discretion.

3. The summary indicator is the product of the ratio of local-government taxes to GDP and the degree of discretion to set taxes independently. Thus, it measures local-government taxes with full discretion as a percentage of GDP.

Source: OECD (1999).

11. Having devolved the responsibility for most public services to counties and municipalities, the government and the parliament cannot exert direct control over total public-sector activity. While this problem is equally relevant in Norway and Sweden, those countries have put legal constraints on counties' and municipalities' right to set their own tax rates, although they were recently lifted in Sweden's case. Danish governments have largely abstained from such direct intervention. Instead, Denmark has opted for a system of formalised budget co-operation between the central government and local government associations. The roots of this system go back to the early 1970s and developed into formal annual negotiations as from 1980.

12. As their core elements the resulting agreements stipulate aggregate expenditure levels and tax rates, and - subject to subsequent parliamentary support - set the size of untied (block) grants. At the initiative of the central government, they have also come to play an important role in stating objectives and establishing new initiatives in individual policy areas. Thus, treatment of specific policy areas have become more prevalent in the agreements in recent years. These vary in their level of detail and the degree of commitment imposed on the parties. In some cases, specific targets have been stated, for example for

5. Thus, legal constraints on the taxing powers have been applied on a few occasions in the past. The tax rates for both counties and municipalities were determined by law in the fiscal year 1971/72 and — for the counties only - were capped in 1988. In addition, legal sanctions in case of non-compliance with the agreements could be used during a few years in the mid-1980s. 
the development of additional childcare places and hospital operations undertaken. In other cases, they have been limited to declarations of intent and highlighting of priority areas.

13. The timing of the negotiations is dictated by the legal requirement that the Ministry of the Interior must inform individual counties and municipalities about the size of their block grant for the coming year by 1 July at the latest. This is to allow local governments enough time to determine their budgets by 15 October. Consequently, the agreements are typically reached in early June and the voting in the parliament's finance committee takes place one or two weeks later. The precedence has been established whereby the proposed block grant is routinely passed by a big majority in the committee if it originates from an agreement between the central government and local government associations.

14. As the local government associations cannot act legally on behalf of their members, the agreements are not binding for individual counties and municipalities. The strength of the agreement framework therefore relies crucially on the associations' ability (despite a lack of efficient instruments) to ensure aggregate compliance. In practice, the compliance has been far from complete (see below). The average tax rate is revealed only when the local governments submit their budgets in mid-October. Nevertheless, and despite these shortcomings, the central government has invested more time and prestige in the budget co-operation process in recent years.

\section{Assessing public expenditure outcomes in selected areas}

15. Assessing how well existing frameworks and policies function in ensuring or encouraging good outcomes is a very complex task, particularly in a cross-country context. The scarcity of unambiguous indicators of good performance as well as problems of properly accounting for differences in stated policy objectives would often render decisive judgements difficult, and an overall rating would hardly be meaningful. Instead, the following sections provide some selective analysis and assessments of performance in four areas, namely childcare, elderly care, education and health. These spending areas, which accounted for two-thirds of public consumption in 2000, have risen more rapidly over the 1990s than have other spending components, and are high by international standards. In large part, this is the result of a deliberate policy to facilitate high female labour force participation (Figure 4). Thus, care and support functions that were earlier attended to within the families have increasingly been taken over by the public sector. While this is a trend that has been visible in many other countries as well, it manifested itself earlier and more clearly in the Scandinavian countries than elsewhere.

\section{Childcare spending surged in the 1990s}

16. In principle, childcare services are not rationed; the objective is that all parents, regardless of their work status, have a right to day care places on demand. Public-sector outlays on day care are high by international standards, owing both to high staff-ratios (and, therefore, unit costs) and broad coverage. At 69 per cent, the coverage rate, i.e. the provision of day-care places as a percentage of the number of pre-school children, was significantly above the levels in other European countries already in 1996 (Table 2), and it has risen since then to 75 per cent in 2001. In particular, the coverage rates for children aged six months to three years are higher in Denmark than elsewhere. Consequently, gross public expenditure for formal out-of-home day care was also higher than elsewhere. However, it should be observed that the total leave period and/or tax credits for at-home care are less generous than in many other European countries, including Sweden, Finland, France and Germany.

17. While a gradual shift to cheaper modes of care has facilitated a decline in real unit costs over the 1990s, real public spending has nonetheless increased as much as 5 per cent per year on average over the past decade. Demographic needs explain some of the increase, but, in addition, coverage has broadened in 
Figure 4. Public consumption on education, health and social services and female participation rate, 1995
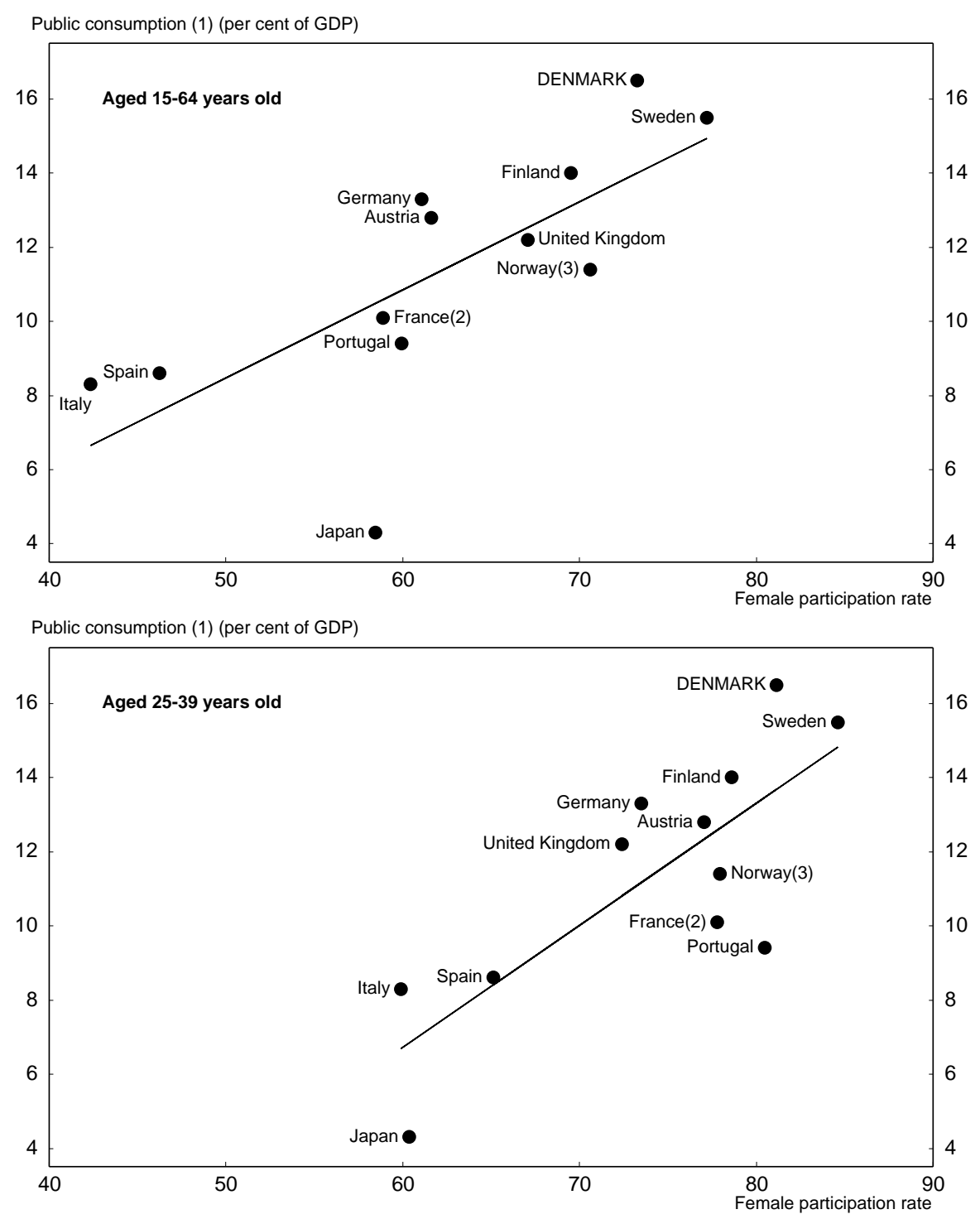

1. On education, health and social services.

2. 1993.

3. 1991.

Source: OECD.

two respects. First, the proportion of children aged six months to nine years attending childcare facilities has risen from less than 60 per cent in the beginning of the decade to more than 80 per cent in 2000, owing in part to a rapid expansion of after-school services for children between six and nine years of age. A broadly similar trend has been observed in most other countries for pre-school care but not for after-school 
Table 2. Out-of-home childcare in selected European countries, 1996

\begin{tabular}{|c|c|c|c|c|c|c|c|}
\hline & Denmark & Sweden & Finland & Germany & France & Netherlands & $\begin{array}{l}\text { United } \\
\text { Kingdom }\end{array}$ \\
\hline Gross public expenditure ${ }^{1}$ & 2.0 & 1.3 & 1.1 & 0.4 & 0.9 & - & 1.3 \\
\hline Provision of full-time places ${ }^{2}$ & 69 & 61 & 42 & 38 & 60 & 28 & 41 \\
\hline \multicolumn{8}{|l|}{ Recommended staff ratio ${ }^{3}$} \\
\hline $0-2$ years & $1: 3$ & - & $1: 4$ & $1: 5-7$ & $1: 5-8$ & $1: 4$ & $1: 3$ \\
\hline $3-6$ years & $1: 6$ & $1: 5$ & $1: 7$ & $1: 10-14$ & $1: 27$ & $1: 8$ & $1: 8$ \\
\hline Unit costs ${ }^{4}$ & 5664 & 3210 & 3665 & 4648 & 3487 & 3630 & 4910 \\
\hline
\end{tabular}

1. Expenditure for formal day care. Per cent of GDP.

2. Per cent of pre-school children.

3. Staff ratios in day care centres, except for France (3 to 6 years) where data refer to nursery school, which almost all children in this age group attend. In a few cases, the staff ratios reported in the table do not correspond exactly to the age group. Full details are available in Rostgaard and Fridberg (1998).

4. Expenditure per child in pre-primary centre-based care on public and private institutions in (US dollars converted using PPPs). Based on full-time equivalents.

Source: OECD Social Expenditure Data Base, OECD (2001a) and Rostgaard and Fridberg (1998).

facilities (OECD, 2001b). ${ }^{6}$ Second, part-time day care places for children of pre-school age have largely been closed down and replaced by more expensive full-time places, thereby implying a considerable standardisation of services. The surge in demand and provision of childcare is partly a response to a reduction of user charges in the early $1990 \mathrm{~s}^{7}$ and the fact that these do not increase in accordance with the number of hours per week children actually attend the facilities. While childcare subsidies are generally economically justifiable on grounds of significant externalities (see, for example, Blomquist, 1999), the surge in childcare spending over the past decade has not been accompanied by higher labour force participation. On the contrary, participation rates among men and - in particular - women aged 25 to 39 years have declined in the same period (OECD, 2000). In part, this is attributable to the introduction in 1994, of a parental leave scheme in addition to maternity leave. But in itself, the parental leave should have reduced the demand for out-of-home childcare. In sum, the current extensive provision is likely to result to some extent from excessive demand. This could probably be reduced by redesigning user charges to reflect on the number of hours of attendance, although marginal prices should not be set so high that they risk encouraging full-time secondary earners to reduce working hours.

\section{Elderly care would benefit from introducing demand signals consistently}

18. Care for the elderly is a municipal responsibility and mainly comprises nursing homes and personal and practical home help (the latter being mainly cleaning, doing the laundry and shopping). Denmark has successfully pursued a policy of making it feasible for the elderly to stay as long as possible in their own homes. The number of places in nursing homes has been reduced over the past 20 years, while sheltered accommodation and home help services have increased in scope. Meals aside, all services are provided free of charge. Although client-choice models have been introduced in a few places, the vast majority of municipalities provides the services themselves. Spending control is exercised exclusively

6. The supply of after-school facilities has tended to create its own demand through a sort of network externality: parents may have felt forced to send their children to an after-school facility because most other children go there, so there is nobody to play with at home.

7. A 50 per cent "brothers and sisters" discount was introduced in 1991. Thus, parents with more than one child in public day care pay full user charges for the most expensive place and 50 per cent of the normal charge for subsequent places. 
through staffing policies and discretionary assessment of need. The move from nursing homes to cheaper services has contained unit costs, and the eligibility criteria implicitly embodied in the assessment of need have generally been tightened in recent years. Total spending has remained stable as a percentage of GDP over the past decade, but at a high level by international standards, in large part because the public sector had already assumed much of the responsibility for elderly care in the 1960s and 1970s. Moreover, nursing home staff ratios are much higher than elsewhere in Europe, except Sweden (Figure 5).

\section{Figure 5. Full-time staff of home help and residents in institutional care} For 100 recipients, latest available years

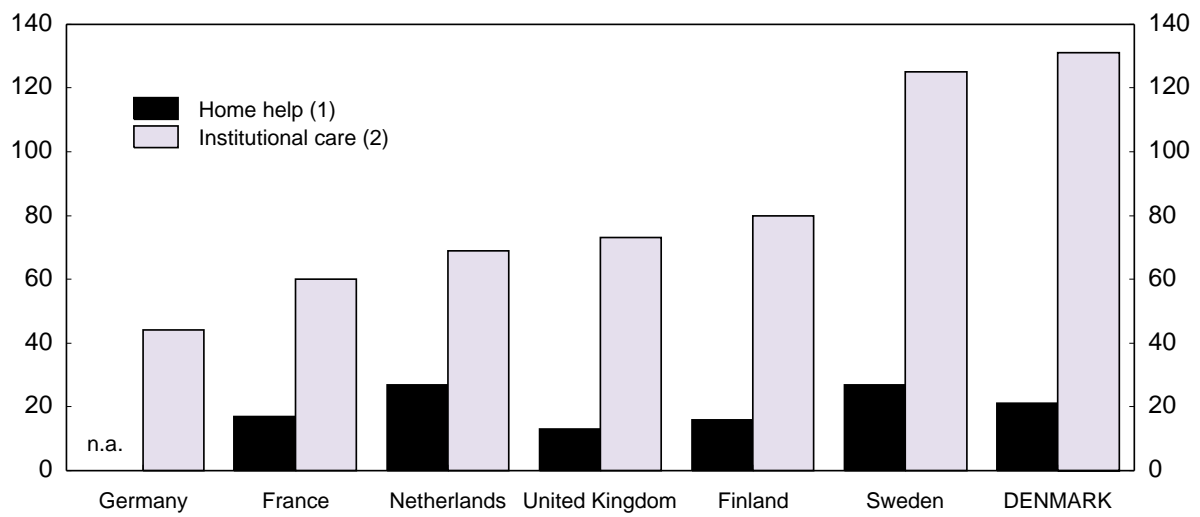

1. Finland, France and the Netherlands: 1996; United Kingdom: 1995; Germany and Sweden: 1994; Denmark: 1992; figures for institutional care only include municipal nursing homes.

2. Finland: 1996; France: home nursing 1996; England and the Netherlands: 1995; Denmark: 1992; Sweden: 1989. Source: Joint Committee on Taxation (2001b).

19. While spending control per se is thus far less of a concern for elderly care, it may increasingly become so in the future. The news media have reported concerns that legitimate demand is being suppressed and that quality is suffering. While a thorough assessment of such claims is beyond the scope of this chapter, ${ }^{8}$ it seems safe to conclude that clients do not benefit fully from the resources allocated, as absenteeism is high. Moreover, it is clear that the sector is extremely supply-side controlled, with market signals and user choice being negligible. Competition is weak or non-existent, and political resistance against user charges is widespread and profound, not only for care services but also for practical help. Moreover, while the municipalities have a legal obligation to provide care and support to those in need, the assessment of need itself is undertaken by the individual municipalities with few restrictions.

20. It may prove difficult to sustain the strict supply-side rationing in the longer term, and policymakers should allow demand signals to play a greater role. At the same time, abandoning the municipalities' obligation to provide practical help could free resources for personal care. While assessment of need is a necessary tool for containing public spending, the case for using it as a means to curb total demand is weak. More scope for client choice both of providers and service standards, would in itself further welfare, but to limit a surge in demand it could be accompanied by private co-payment either

8. Finansministeriet $(2000 a)$ reports results from a recent survey of satisfaction with elderly care, which suggest that the perceived quality is lower for practical help than for other services. Moreover, non-users are found to be distinctly less satisfied than users, a result also seen in similar surveys in other areas. 
as individual user charges or via insurance schemes. ${ }^{9}$ Indeed, elderly care lends itself well to private insurance solutions. Such insurance schemes could finance supplementary services topping up the basic tax-financed provision but would need to be under public regulation. One possible advantage of insurance schemes could be greater transparency by stating entitlement criteria more explicitly. At present, effective eligibility criteria may vary considerably across, or even within, municipalities. From the users' viewpoint, this is both arbitrary and non-transparent.

21. The government has outlined a reform of elderly care policies in its "working programme". The main thread is to significantly widen the scope of client choice once the eligibility for care or practical help has been positively assessed. This comprises free choice of nursing home or sheltered accommodation (also outside the municipality of residence) and the right to be accompanied by one's spouse; free choice — both for personal care and practical help — between municipal services and private providers (persons or companies); and greater scope for individuals to determine the content of practical help. These are laudable intentions. However, the more extensive rights may also lead to greater demand pressure and user charges should be introduced to prevent a rise in spending. Moreover, to make client choice a reality, it is important that adequate private supply is encouraged, one precondition being that the procedures for certifying private companies are kept as simple as possible.

\section{Evolution of health care policies}

22. From a level of 8 per cent of GDP in 1980, public expenditure on health had fallen to 63/4 per cent of GDP by 1998 . While the 1980 level was distinctly high by international standards, the current level is comparable with those in most other OECD countries (Table 3). It should be observed that differences in countries' demarcation of health expenditure might to some extent distort the comparison. Two features of the Danish health care sector have been particularly important in restraining expenditure.

- First, the gatekeeper function served by general practitioners prohibits or significantly restricts direct access to other medical services.

- Second, the sector's vertical integration is stronger than in most other OECD countries. The full responsibility for planning, operating, financing and economic management of all essential parts of the sector is concentrated at one level of government - the counties (Pedersen, 1999). For example, the agreements on general practitioners' remuneration is negotiated by the association of county councils, who also own, operate and finance hospitals.

23. This strong vertical integration has helped facilitate expenditure control, for example through budget envelopes for individual hospitals. No individual user charges apply for primary and secondary health services, and user choice in the latter is limited. Patients have had the right to choose hospital services outside their own county since 1994, but such factors as insufficient information and strong preferences for treatment at the local hospital have limited the exercise of that privilege. The government has proposed to extend the patients' choice to include private hospitals, which should help to encourage more competition and efficiency. However, at the same time it weakens the vertically integrated structure (because the counties would no longer own and operate all hospitals) and it could prove to be difficult to reconcile with the budget-envelope approach (see below).

9. The political resistance against user charges is founded on distribution concerns, but it is both illogical (see Box 1 below) and inconsistent. For example, it is not obvious why differences in housing standards for elderly receiving help in nursing homes are deemed unacceptable while they are not for those receiving help in their own homes. 
ECO/WKP(2002)6

Table 3. Public expenditure on health, 1998

Per cent of GDP

\begin{tabular}{|c|c|c|c|c|c|}
\hline & \multirow[b]{2}{*}{$\begin{array}{c}\text { Public } \\
\text { expenditure on } \\
\text { health }^{1}\end{array}$} & \multicolumn{4}{|c|}{ National accounts consumption of health services } \\
\hline & & $\begin{array}{l}\text { Health related } \\
\text { transfers to } \\
\text { households }\end{array}$ & Public sector $^{3}$ & Private $^{4}$ & Total \\
\hline Australia & 5.9 & 2.1 & 3.0 & 5.1 & 8.1 \\
\hline Austria & 5.8 & 0.1 & 5.5 & 2.2 & 7.7 \\
\hline Belgium & 7.9 & - & - & 7.7 & - \\
\hline Canada & 6.6 & - & 6.6 & 2.4 & 9.0 \\
\hline Denmark & 6.8 & 0.0 & 5.0 & 1.5 & 6.5 \\
\hline Finland & 5.3 & 1.0 & 4.3 & 2.8 & 7.1 \\
\hline France & 7.3 & 6.6 & 3.4 & 6.2 & 9.6 \\
\hline Germany & 7.9 & - & 6.4 & 2.1 & 8.5 \\
\hline Ireland & 4.8 & 0.5 & 4.4 & 2.0 & 6.4 \\
\hline Italy & 5.7 & 1.9 & 3.4 & 4.1 & 7.5 \\
\hline Japan & 6.0 & 4.9 & 0.4 & 6.3 & 6.7 \\
\hline Netherlands & 6.0 & 6.9 & - & 5.7 & 5.7 \\
\hline New Zealand & 6.2 & 2.2 & 2.8 & 5.1 & 7.9 \\
\hline Norway & 7.4 & - & 5.7 & 1.3 & 7.0 \\
\hline Portugal & 5.2 & - & 3.3 & 3.4 & 6.7 \\
\hline Spain & 5.4 & 1.3 & 4.3 & 3.2 & 7.5 \\
\hline Sweden & 7.0 & - & 4.6 & 2.0 & 6.6 \\
\hline Switzerland & 7.7 & 0.6 & 1.5 & 7.8 & 9.3 \\
\hline United Kingdom & 5.6 & 0.1 & 5.3 & 1.0 & 6.3 \\
\hline United States & 6.1 & 4.7 & 1.3 & 12.4 & 13.7 \\
\hline Country mean & 6.3 & 2.4 & 4.0 & 4.0 & 7.8 \\
\hline
\end{tabular}

1. As defined in the OECD health data base.

2. Finland, Ireland and the Netherlands (1997); Spain and Japan (1996); Italy (1995); France (1993).

3. Finland and Ireland (1997); Australia, Japan and Norway (1996); Canada, France, Italy and Sweden (1995); Spain (1994); France and Portugal (1993).

4. Australia, Canada, Finland, Ireland and Spain (1997); Belgium, France, Germany, Italy, Japan, Norway and Sweden (1996); Portugal (1995).

Source: OECD Health Data Base.

24. Meanwhile, the supply-side-governed hospital sector needs to respond, if only indirectly, to demand signals in order to contain strains that might otherwise arise from a mismatch between demand and supply. Increasing average waiting times in the first half of the 1990s have led policymakers to channel additional resources to the hospital sector in recent years, and the decline in total expenditure since 1980 has bottomed out. However, despite rapid increase in the number of hospital treatments, average waiting times have not yet started to shorten. In 2000, the average waiting time for elective surgical overnight-stay patients was around 100 days (Ministry of Health, 2001). Maximum waiting periods have been guaranteed for an increasing number of treatments.

25. Most recently, the government has proposed allocating an additional $\mathrm{DKr} 1 \frac{1}{2}$ billion to the health-care sector in 2002 and giving all patients the right, as from 1 July 2002, to seek treatment at a private or foreign hospital, if treatment has not been offered by the public health-care system within a period of two months. Considering the highly strained capacity situation in the sector, patients will 
probably have to be willing to accept treatment abroad if effective waiting times are to be reduced significantly in the near term. Even if productivity is improved, the capacity of the sector needs to be expanded to gradually achieve a significant shortening of effective waiting periods. While the size of the implied increase in spending is uncertain, the basic point is that a commitment to a general maximum waiting period would imply de facto a big step in the direction of linking, more formally, appropriations to "demand" with accordingly higher budget costs. However, it is a question whether the capacity can realistically be expanded without an increase in real unit costs. In particular, it has been difficult for a number of years to attract new staff on the scale required just to compensate the annual outflow into retirement and other activities. While this has probably multiple explanations, relative wage levels could easily be one of them.

26. A sign of potential strain in the hospital sector is the apparently growing interest in private health-insurance schemes financed primarily by employers. Such medical insurance has hitherto been discouraged by insufficient private sector capacity and the absence of any public subsidies to treatment in private hospitals. While these remain important barriers, ${ }^{10}$ evidence is spreading that private funds are increasingly available to pay the costs of overcoming them, at least for certain groups of employees or citizens. It is premature to assess how big a market could evolve in the future, but policy makers could face a difficult choice. On the one hand, maintaining strict expenditure control may encourage the emergence of a supplementary private insurance market and a growing private hospital sector and thus compromise the traditional objective of "free and equal access". On the other hand, adding enough resources to the public hospital sector to satisfy the demand of those groups who are most willing to pay, thereby discouraging supplementary private solutions, may prove to be expensive.

\section{Education is costly compared with the outcome}

27. At 8.3 per cent of GDP in 1998 Denmark's total spending on education is slightly above the levels in Sweden and Norway and significantly higher than in any other OECD country (Table 4). The higher level of public educational expenditure can be put down to four main factors. First, unit costs are very high by international standards in primary and lower secondary education. Second, outlays for adult and vocational training are distinctly high, reflecting the priority given to active labour market policies as well as remarkably generous subsidies to leisure time education and employers' training of their staff. Third, while private-sector co-payments in tertiary education are significant in a number of countries, they are negligible in Denmark. Hence, education expenditure is largely publicly provided and tax financed. Finally, as in the other Scandinavian countries, the student grants scheme is very generous, thereby contributing to the high spending level, although this does restore incentives to invest in human capital, which are depressed by the compressed wage structure.

10. The right to choose private hospitals implies that "the money goes with the patient". However, according to the government's "working programme", private hospitals are not allowed to charge for services provided under the imminent client choice programme. 
Table 4. Spending and unit costs at various levels of education

\begin{tabular}{|c|c|c|c|c|c|c|c|c|}
\hline \multirow[b]{4}{*}{ Australia } & \multicolumn{4}{|c|}{ Public spending } & \multirow{2}{*}{$\begin{array}{c}\text { Total spending } \\
\text { All levels of } \\
\text { education }^{2}\end{array}$} & \multicolumn{3}{|c|}{ Unit costs } \\
\hline & $\begin{array}{l}\text { Primary and } \\
\text { Secondary }\end{array}$ & Tertiary & $\begin{array}{c}\text { of which: } \\
\text { Student grants }\end{array}$ & $\begin{array}{l}\text { All levels of } \\
\text { education }^{2}\end{array}$ & & Primary & Secondary & Tertiary \\
\hline & \multicolumn{5}{|c|}{ Per cent of GDP } & \multicolumn{3}{|c|}{$\begin{array}{c}\text { Expenditure } \\
\text { per full-time student relative to GDP per capita }{ }^{3}\end{array}$} \\
\hline & 3.5 & 1.2 & 0.1 & 4.8 & 5.9 & 16.0 & 24.0 & 48.0 \\
\hline Austria & 4.0 & 1.6 & 0.2 & 6.3 & 6.5 & 26.0 & 35.0 & 48.0 \\
\hline Belgium & 3.5 & 1.1 & 0.2 & 5.2 & - & - & - & - \\
\hline Canada & 3.7 & 1.8 & 0.3 & 5.7 & 6.3 & - & - & - \\
\hline Denmark & 4.9 & 2.2 & 0.7 & 8.3 & 8.4 & 26.0 & 28.0 & 37.0 \\
\hline Finland & 3.8 & 2.0 & 0.3 & 6.2 & - & 21.0 & 23.0 & 34.0 \\
\hline France & 4.2 & 1.0 & 0.0 & 6.0 & 6.3 & 18.0 & 31.0 & 34.0 \\
\hline Germany & 3.0 & 1.1 & 0.1 & 4.6 & 5.6 & 15.0 & 27.0 & 41.0 \\
\hline Greece & 2.3 & 1.1 & 0.1 & 3.5 & 4.8 & 17.0 & 23.0 & 29.0 \\
\hline Ireland & 3.3 & 1.1 & 0.0 & 4.5 & 4.9 & 12.0 & 17.0 & 38.0 \\
\hline Italy & 3.5 & 0.8 & 0.1 & 4.9 & 5.1 & 26.0 & 29.0 & 28.0 \\
\hline Japan & 2.8 & 0.4 & 0.0 & 3.5 & 4.4 & 21.0 & 24.0 & 41.0 \\
\hline Netherlands & 3.1 & 1.4 & 0.2 & 4.9 & 5.0 & 15.0 & 21.0 & 44.0 \\
\hline New Zealand & 4.9 & 1.8 & 0.7 & 7.2 & - & - & - & - \\
\hline Norway & 4.6 & 2.0 & 0.6 & 7.7 & 7.8 & 22.0 & 28.0 & 42.0 \\
\hline Portugal & 4.3 & 1.0 & 0.0 & 5.7 & 5.8 & 21.0 & 29.0 & - \\
\hline Spain & 3.3 & 0.9 & 0.1 & 4.5 & 5.2 & 19.0 & 27.0 & 30.0 \\
\hline Sweden & 5.3 & 2.1 & 0.6 & 8.0 & 8.2 & 26.0 & 26.0 & 61.0 \\
\hline Switzerland & 4.1 & 1.1 & 0.0 & 5.5 & 6.0 & 24.0 & 34.0 & 61.0 \\
\hline United Kingdom & 3.4 & 1.1 & 0.3 & 4.9 & 5.2 & 15.0 & 24.0 & 45.0 \\
\hline United States & 3.4 & 1.3 & 0.2 & 5.1 & 6.7 & 19.0 & 24.0 & 61.0 \\
\hline Country mean & 3.8 & 1.3 & 0.2 & 5.6 & 6.0 & 19.9 & 26.3 & 40.1 \\
\hline
\end{tabular}

1. Includes post-secondary non-tertiary education.

2. Includes undistributed outlays and advanced research programmes. Undistributed outlays for programmes that do not conform to international classifications are above average in Denmark. This reflects high spending on leisure-time education as well as adult and vocational education partly in the context of active labour market policies.

3. Multiplied by 100. Includes both public and private institutions except for Austria, Norway, Italy, Portugal and Switzerland where data refer to public institutions only and Greece and United Kingdom for which they concern public and government-dependent institutions. Source: OECD. 
28. A notable feature of Danish education policies is the relatively high priority given to primary and lower secondary education relative to tertiary education:

- Primary and lower secondary education are costly (relative to GDP) by international standards, but the greater resources are not matched by correspondingly better schooling outcomes. ${ }^{11}$ The high spending level is mainly due to high unit costs, as Denmark has the lowest student-to-staff ratio in the OECD area. However, this is not reflected in higher annual instruction hours and only partly in smaller class sizes. Instead, it is because teachers teach fewer classroom hours than elsewhere - this has been recognised by policy makers as unwarranted. Faced with the prospect that the parliament would otherwise impose legislation, the teachers' union agreed to new work time rules as part of the 1998 collective agreement. But the new rules intended to increase the average number of instruction hours do not yet seem to have delivered on this count. Moreover, the teacher's union has indicated that it may discontinue the agreement when it comes up for renewal in 2002.

- For tertiary education, total expenditure relative to GDP is close to the unweighted average level in the countries reported in Table 4 but lower than the weighted OECD total, which is boosted considerably by the high spending level in the United States. This reflects above-average public spending in Denmark and below-average private funding. While enrolment rates in tertiary education are fairly high, unit costs are relatively low.

29. The current composition of education expenditure results, in part, from an upward trend in unit costs within primary and lower secondary education since 1980, combined with a fall for tertiary education (Figure 6). This suggests asymmetric behaviour, at least for primary and secondary education: total spending in this sector tends to adjust upwards when the number of students rises, but fails to adjust downwards when numbers decline (Finansministeriet, 1999a and Heinesen, 2000). This difference is likely to be the combined result of several factors, two of which are mentioned here.

- First, most staff in the primary and lower secondary sectors are on permanent contracts, and the degree of unionisation is very high. In contrast, a large part of the teaching in the tertiary sector is undertaken by external part-time teachers, typically on temporary contracts. These differences may reduce flexibility and the variability of total costs in the primary and lower secondary sector (at least in the short run) because of union resistance against spending cuts.

- Second, the responsibility for primary education lies with the municipalities, upper secondary education with the counties, and tertiary education with the state. Unit costs have increased most at the most decentralised levels of government and least at the central level. It seems plausible that client involvement and awareness is greater at the local level, which tends to strengthen the position of spending advocates.

30. A separate issue is adult and vocational education, which comprises courses and formal education for the unemployed and training of employees, as well as leisure time education. At more than one per cent of GDP, public expenditure is significantly above that in other countries. ${ }^{12}$ This reflects political preferences and has not been justified on economic arguments, for example from cost-benefit analyses.

11. Results from the 2000 survey of the OECD's Programme for International Student Assessment (PISA) indicate that the reading skills of Danish 15 year olds are close to the OECD average, while skills in mathematics are above average and scientific literacy below average (OECD, 2001c).

12. International standards for classification and demarcation of adult and vocational education do not exist, impeding cross-country comparisons. Nonetheless, the higher figure for "undistributed" educational spending in Table 4 above suggests that expenditure in this area is higher than in most other countries. 
While public spending in this sub-sector is prevalent in most countries, the Danish system is distinctly generous on two counts.

- First, subsidies for leisure-time education are significant both in coverage and on a per-student basis. While unit costs vary significantly between the specific types of education, they are generally very high compared with other types of education. In "folk high schools", 13 for example, the annual public unit cost of a full-time student is 25 per cent above the average level for tertiary education, and only 10 per cent below the most expensive types of tertiary education.

- Second, Denmark stands out as virtually the only country in which recurrent training of the employed enjoys non-negligible public subsidies (OECD, 2001d). In addition to often paying the full costs of providing vocational training courses even for people in employment, the government also pays a benefit to the participants in such courses (thereby freeing the employer from the wage costs) as well as compensation for transportation costs. In some cases, economic externalities may be large enough to justify some subsidies, but in general these payments should be cut back significantly and, as a minimum, sizeable user charges should be levied.

Figure 6. Real unit costs at various levels of education ${ }^{1}$ $1980=100$

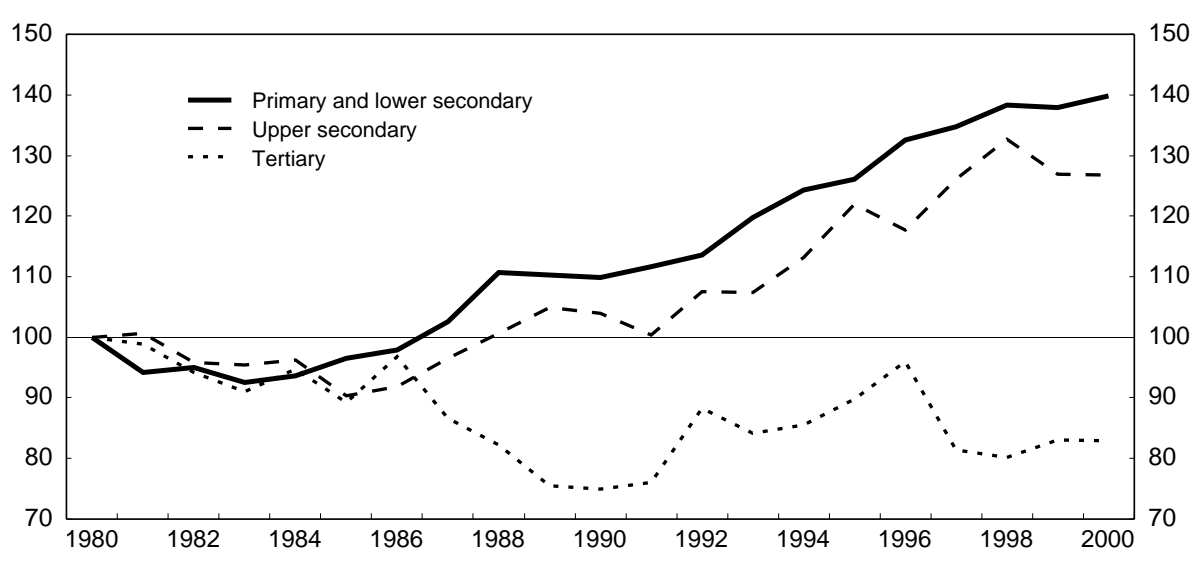

1. Unit costs deflated by the index used for constant-price calculations by the Ministry of Finance in the Budget. The main input to the index is the evolution of public-sector wages. Source: Ministry of Finance.

\section{Challenges and scope for changes in policy frameworks}

31. This section provides a discussion of the scope for adjusting current policy frameworks in ways that may further the broad and general objective of optimising the use of public funds, i.e. providing high-quality services and income support to the right people at the lowest possible cost, thereby mitigating, as much as possible, the distortionary effects from the tax financing. The focus is largely on institutional

13. "Folk high schools" (folkehфjskoler) have a tradition of more than 150 years. They are independent, private, non-examination boarding schools providing courses over shorter or longer periods. Subject to the approval by the Minister of Education of their foundations, they are eligible for government subsidies on a per-student basis. The schools are open to all and determine their curricula themselves. 
adjustments and cross-sector instruments (in contrast to the above sector-specific policies). The discussion will proceed in four stages: reforming the budget process; managing local governments; encouraging competition and extending market signals; and enhancing administrative efficiency.

\section{Reforming the budget process}

32. The main deficiency of the budget process (which is described in more detail in Annex II) is the absence of a binding expenditure ceiling and the resulting risk of discretionary slippage in the political discussions that take place between the presentation and the adoption of the budget. The fiscal balance, as such, has not been a big concern, as additional spending has typically been financed by higher revenues. But no firm mechanisms have acted to prevent a ratcheting-up of both expenditure and taxes. The multi-annual budget framework has so far been of little use in this respect, as amendments to the budget are typically added to the ministerial expenditure ceilings of subsequent years. On several counts, in particular for entitlement outlays, the three budget forecast years are largely a mechanical prolongation. The multi-year budgeting framework should be improved to facilitate early identification of problems and better integration with the overall medium-term economic strategy.

33. Another concern is that the state budget is adopted after those of local governments, but nonetheless it has frequently contained last-minute amendments that impact on their economic situation. This weakens the transparency of the budget process for the general government sector as a whole. One way of addressing both problems would be to have the parliament vote on the level of total expenditure for the coming fiscal year early in the process. ${ }^{14}$ In addition to furthering transparency and parliament involvement in the budget process this would strengthen its top-down character and weaken the current "patchwork-approach" to policy making. ${ }^{15}$ Such a vote should be taken before the commencement of the negotiations between the central and local governments, and the ceiling should include central-government grants to local governments. While the details would obviously have to be analysed further, a stronger political commitment is the prime precondition for an expenditure target to be efficient. The government has stated its intention to restrain public expenditure, and the declared "tax freeze" is intended to reinforce that commitment. Indeed, the pledge to not raise any taxes would put the fiscal balance at greater risk unless expenditure is also reined in more tightly. Nevertheless, instituting an overall expenditure ceiling would further underpin a tight spending stance and safeguard the fiscal surplus.

\section{Managing local governments}

34. The merits of a highly decentralised public sector may be compromised if governance structures and the regulatory framework are not well aligned. One challenge is that the central government cannot directly control the implementation of many sectoral policies, nor total public spending, but must act indirectly through regulation of local governments' activities. Moreover, if economies of scale are significant, it would be important for overall efficiency to match the devolution of responsibilities with the size structure of local governments. The following sections provide a discussion of some of the issues in intergovernmental relationships where policy reforms might be warranted.

14. This should be seen as a complement to further developing the framework for sound micro-budgeting (see below).

15. In recent years, new elements in the budget have been supported by varying majority coalitions on a case-by-case basis - thereby giving rise to the patchwork characterisation. The budget bill itself is voted upon separately and is typically passed by a broad majority. 


\section{Unclear governance structure weakens accountability}

35. Following almost three decades of continuous decentralisation, some reversal is apparent, although only a few responsibilities have formally been moved back to the central government. The government and parliament are increasingly engaging in setting standards and micro-managing local governments' implementation of sectoral policies (Box 1). This reflects, de facto, less willingness by central-government politicians to accept variations in service levels and standards across municipalities. Such differences have indeed narrowed.

\section{Box 1. Micro-managing local governments}

The annual agreements with local governments have become steadily more detailed over the past decade, both specifying desired policies and outcomes in various sectors and in nailing down technical details in the text itself. This could be interpreted as indicating a fundamental conflict between local government autonomy and the central government's ambition to control policy developments even in areas that have been devolved.

In the health care sector, the government has increasingly taken over formulating policies and determining priorities. In particular, this is manifest in the national programmes in specific areas such as cardio-vascular disease, cancer and psychiatric illness. On the central government's initiative, the 2002 Agreement with the counties stated the objective of reducing maximum waiting periods for all hospital treatment to three months over a three-year period. A few very specific programmes, for example, screening for breast cancer, have been imposed on all counties. The commitment to reducing waiting periods has been reinforced by the government's client choice programme described above.

The fiscal bill in recent years has typically included initiatives with consequences for the lower levels of government, even in allocating additional funds to services for which local governments are responsible. As agreements on the fiscal bill are reached after local governments' budgets are adopted, this affects the transparency of the whole budget process.

Legal regulation is perceived to have increased in scope and detail. One of the most obvious examples is the Social Services Act of 1998, which strengthened appeal possibilities, introduced user councils in new areas and obliged local governments to draw up service declarations to a greater extent than before. The aim of this line of policy, which has been taken furthest within elderly care, is to clarify and ensure individuals' legal rights, contain expectations at realistic levels and strengthen transparency in general. While these are laudable objectives, they may unintentionally add to demand-side pressures rather than curb them.

36. Despite the much greater involvement of the central government in many spending areas, local governments' taxing powers have remained untouched, and the framework for economic management of counties and municipalities have been left largely unchanged for more than a decade. More direct and thorough central government control risks compromising the logic of the decentralised system in two important ways.

- First, some of the potential benefits - richer local democracy and adjustment to local needs and preferences - are obviously weakened the more the central government interferes, and the case for local-government tax financing is weakened. The example of secondary health care may serve to illustrate this; effectuating the government's client choice programme basically implies that the level of activity will be determined by what is required to comply with a general maximum waiting period of two months. This leaves little scope for the counties to prioritise resources and it is not obvious, therefore, that the funding is best placed with the counties.

- Second, accountability is likely to suffer. Repeatedly, local governments have blamed overruns on agreed spending levels and tax rates on centrally imposed regulation and 
objectives; and equally often parliamentarians have criticised local governments for not meeting centrally initiated objectives in certain spending areas as well as for not complying with the agreed tax rates. By increasingly micro-managing on the expenditure side but leaving taxing powers unchanged, the central government has effectively separated the discretion to decide policies and service levels from the responsibility to finance spending.

There is a strong need for realigning these two powers and for clarifying the responsibilities between the various levels of government more generally. In those areas where the central government specifies standards and imposes detailed regulation, it might as well also take over the financial responsibility and compensate local governments through direct reimbursements. Conversely, where local-government tax financing is deemed warranted, the central government should abstain from excessive micro-management.

\section{Overall expenditure control needs to be enhanced}

37. As local governments' spending accounts for more than half of total public sector outlays, controlling their aggregate expenditure is of paramount importance. However, the formalised budget co-operation between the central and local governments has failed to deliver on this count. Local governments have typically responded to negative deviations from their budget targets by raising revenues more than cutting expenditures, and to positive surprises by increasing spending more than reducing taxes (Rattsø and Tovmo, 1997). Practically all annual agreements between the various levels of government since 1984 have included targets for the aggregate tax rate. Although some increases were accepted in the second half of the 1990s (primarily at the county level), the agreed levels of block grants from the central government have typically assumed unchanged tax rates. However, the actual outcome has been a steady upward trajectory for both counties and municipalities. The actual changes in tax rates have exceeded agreed changes in 11 out of the past 18 years (Figure 7). The cumulative increase in local governments' income tax rates in this period has been 5 percentage points of which only $1 \frac{1 / 4}{4}$ percentage points were foreseen in the agreements themselves. ${ }^{16}$ While local governments obviously bear a substantial part of the responsibility for this outcome, the unclear governance structure, which falls back on the central government, also contributed.

16. This updrift in tax rates was a continuation of the trend of the 1970s and the 1980s; thus, the average income tax rate of local governments rose more than 7 percentage points between 1970 and 1983. Even though the budget co-operation was less formalised and the agreements less explicit during this period, it is reasonable to assume that a large part of the tax increases even prior to 1984 was considered unwelcome ex ante. Thus, when the PPII-report (Perspektivplan II) from 1973 recommended formal budget co-operation, it was precisely out of a concern that tax rates would otherwise rise. The temporary freeze of local-government income tax rates in 1971/72 originated from the same concern. It was proposed by the conservative-liberal government then in office as a temporary arrangement until budget co-operation could be established. In a parliamentary reading the social-democratic speaker endorsed the proposal and gave the following statement, which in hindsight is rather thought-provoking: "My party recognises that taxation has reached such a level that the situation would be serious to many taxpayers should further tax increases occur. Therefore, we would like to contribute to reducing taxation ... we recognise that intervention is now necessary" (quoted by Blom-Hansen, 1998). 


\section{Figure 7. Planned and actual income-tax rate increases by local governments ${ }^{1}$ Percentage points}

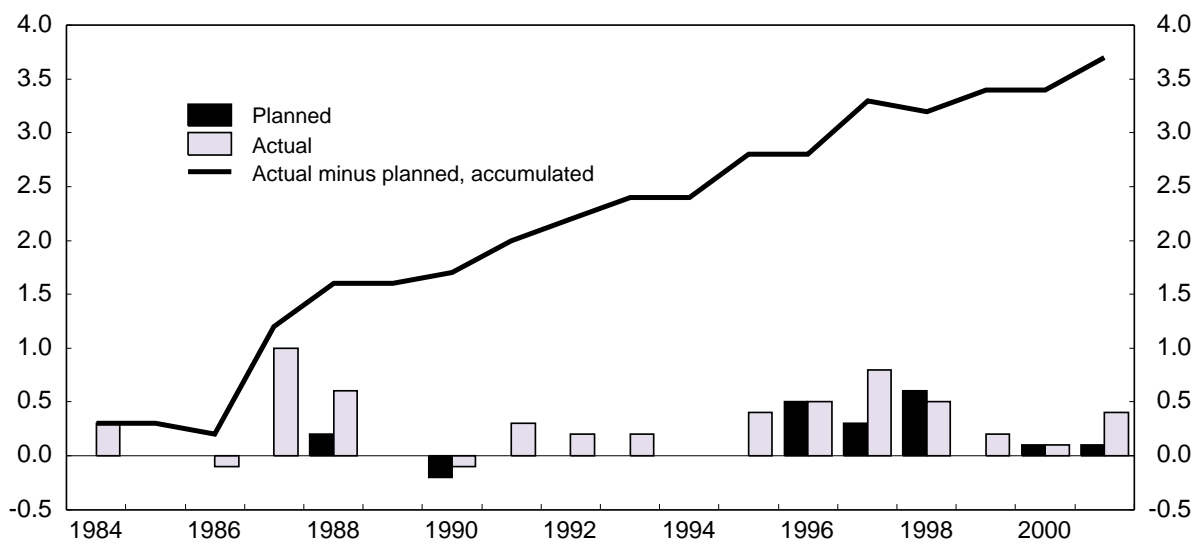

1. "Planned" refers to the annual agreements between the central and local governments, except in 1987 and 1988 , where targets were set unilaterally by the central government. Source: Ministry of the Interior; Statistics Denmark; Blom-Hansen (1996).

38. An innovation in the process of budget co-operation took place in 1998 with the four-year agreement between the central government and the National Association of Local Governments. The agreement was an attempt to focus attention more directly on expenditure developments, both on the side of the municipalities and amongst central government spending ministers. It set a 1 per cent target for the acceptable annual rise in real operating costs, i.e. mainly public consumption, and specified the corresponding expenditure levels for each of the years 1999 to $2002 .{ }^{17}$ In addition, quarterly follow-up meetings between the parties were instituted to enable early action in case of deviations from the set course. However, the average increase in the years 1999 to 2001 was $1 \frac{1}{2} 2$ per cent and, against the backdrop of a generous agreement, the municipalities' budgets suggest a further real increase of around 13/4 per cent in 2002.

39. At least two problems arise from the unplanned upward drift in local governments' income tax rates. First, it is fundamentally unsound to maintain a system that is not complied with; this weakens the central government's credibility and it raises moral hazard problems. Second, individual local governments are unlikely to take into account the national externalities resulting from higher tax rates, i.e. distortion of incentives to work and educate.

40. By not acting in response, the government and the parliament have de facto given their tacit consent to non-compliance. It is the combination of an unclear governance structure, an atomised decision process and extensive taxing powers for individual local governments that has led to weak aggregate expenditure control. While the right for local governments to set their own income tax rates freely is seen by many as the epitome of local-government autonomy, restricting this right could, nonetheless, be necessary because of the negative effects on the overall economy of rising tax rates. ${ }^{18}$ The government has

17. The multi-year character of the agreement applied to the spending level only, as the level of untied grants was still to be subject to annual negotiations. Moreover, in the subsequent years' agreements, explicit expenditure targets have not been set for the years after 2002 .

18. If local differences in (the evolution of) tax rates and expenditure levels fully reflected varying local preferences they might be considered logical and even warranted effects of local democracy. In this case, 
stated that the announced "tax freeze" will also apply to local government taxes, but it has not yet specified any changes to the budget co-operation framework that could ensure this. ${ }^{19}$ One possibility is to impose economic sanctions on those counties and municipalities that raise taxes. Another more flexible approach would be to cap or freeze the income tax rate but allow local governments to fund themselves in other ways, for example by increasing the scope for raising property taxes, lowering taxpayers' basic allowances or reducing the constraints on user charges. ${ }^{20}$ This would safeguard local government autonomy and, at the same time, prevent further detrimental effects on labour supply from the continued upward drift in tax rates.

\section{Are there too many small municipalities?}

41. It is questionable whether the structure that was created three decades ago remains well aligned with the current range of local government responsibilities. The average number of inhabitants per municipality is approximately 19000 , with the 20 smallest municipalities having less than 5000 inhabitants. While this is much smaller than in, for example, Ireland or the United Kingdom, it is considerably bigger than in France, Italy or Spain (Mouritzen, 1999). Thus, the main point is not that Danish municipalities are small by international standards but that the list of their responsibilities is much longer. One possible drawback of the current municipal structure is that it may impede reforms that could encourage competition and user choice (see below).

42. A number of studies indicate that economies of scale in the provision of services are prevalent, even if rather modest (Mouritzen, 1999 and Indenrigsministeriet, 2001). ${ }^{21}$ However, those studies include only the efficiency in the provision of core services and not whether small municipalities have the ability to carry out professional administration of complex tasks such as, for example, assessment of eligibility for early retirement pension; provision of labour market programmes for cash benefit recipients; integration of refugees into the labour market; or environmental supervision of businesses. While empirical evidence is lacking, anecdotal information indicates that this might be a relevant concern, and public debate on the need for a reform of the municipal structure has surfaced. Experience from the 1970 reform suggests that

the Tiebout effect, i.e. that people "vote with their feet", would ensure that actual policies were in keeping with voters' preferences. However, several factors limit the relevance of the Tiebout effect in practice, at least in the Danish context. First, local-level policy makers and their electorates are unlikely to take into account second-round effects on labour supply from raising taxes. Second, moving costs are considerable, and the advantages sought in another jurisdiction may be transient. Finally, the initial premise is not valid in practice. Besides differences in the efficiency of providing services, variation in the trends and levels of local tax rates also reflect incomplete equalisation and the less than full reimbursement of transfer outlays. These factors are beyond local control, which adds to the overall complexity.

19. The government has signalled that it would cut central government taxes accordingly if local government taxes are raised.

20. Some flexibility might also be maintained by putting in place a trading scheme in taxing rights on top of a tax freeze thereby making it possible for counties and municipalities with a preference for increasing spending to buy permits to raise taxes from other counties and municipalities lowering their rates. It is a complicating factor, though, that both the levels and changes in tax rates across local governments reflect much else than local preferences.

21. The economically optimal size is estimated by the Ministry of the Interior to be around 20000 to 30000 inhabitants; beyond this size, there is a weak tendency for costs to rise. Some 200 municipalities (70 per cent) are smaller than this, and the potential annual efficiency gain if, hypothetically, all municipalities were of optimal size (and assuming the same population density in all municipalities) has been estimated to be roughly DKr $13 / 4$ billion, i.e. around 13/4 per cent of total local government outlays. 
building support for such a change can be a politically cumbersome and time-consuming process. ${ }^{22}$ So far, central government policymakers have been reluctant to address the issue of a new reform, but it may become inescapable in the near future. The devolution of the above-mentioned responsibilities, which have mostly taken place over the past decade, has added a new dimension to municipalities' portfolios. On top of the traditional obligations to provide core personal services, they also have the job of ensuring as far as possible that social clients receive "active offers" instead of "passive transfers". It seems rather obvious that authorities with 5000 to 10000 residents have very different conditions for managing this than do those of 50000 to 100000 inhabitants.

\section{Encouraging competition and extending market signals}

43. This section considers ways in which extending market mechanisms, such as contracting out, user charges and client choice, can improve allocative efficiency. If such instruments are not applied, containing expenditures will depend solely on supply-side rationing such as queuing or assessment of need. Both of these instruments have their own inherent weaknesses; a main drawback of queuing is the absence of prioritisation in the allocation process, while assessment of need tends to be a very non-transparent mechanism from the client's point of view. The division of political competence between different levels of government may be an important barrier to strengthening competition and introducing market signals. For example, municipalities have significant discretion in deciding on contracting out, but little freedom to set user charges.

\section{Contracting out}

44. A certain political consensus has emerged in recent years, at least in principle, that exposing public services to competition may be a means of making their provision more efficient and that this can be reconciled with public financing and regulation. Policies governing contracting out are twofold. First, central government authorities are required, by virtue of a Ministry of Finance circular, to call for tenders on all services "regularly". Hitherto, adherence to this requirement has been rather mediocre (Udliciteringsrådet, 2000), and its enforcement needs to be enhanced, for example through the contracts with central government authorities and their directors. Second, individual local governments have considerable freedom to decide their own policies; core administrative responsibilities and primary education aside, there are only few restrictions.

45. A recent study by the Competition Authority on trends in the use of tendering and outsourcing in counties and municipalities suggests that the value of services contracted out has increased only marginally over the past decade (Konkurrencestyrelsen, 2001). ${ }^{23}$ Exposure to competition is highest for technical services, road building and, to a lesser extent, utilities and administration (Table 5). In contrast, contracting out is very limited - around five per cent — in the big spending areas like education, childcare, elderly care and health. In these areas the Danish "level" of contracting out is only half that in Sweden and largely confined to auxiliary services such as cleaning, transport or "meals-on-wheels" services. In sum, the

22. That reform required more than a decade of preparation.

23. On average, services worth 11 per cent of the municipalities' operating costs were contracted out in 1999. A small group of municipalities purchased more than 15 per cent of their services from external providers, while in the large majority of municipalities, the figure was between 7 and 10 per cent. Cross-country comparisons of the use of tendering and outsourcing are impeded by the scarcity of data. Using the proportion of non-wage outlays in total public consumption as an indirect indicator, the share of services produced "in-house" by the Danish public sector appears to be above average — and contracting out thus below average (OECD, 2000). 
diffusion of tendering and outsourcing has progressed only slowly despite extensive public attention and political debate on the issue.

Table 5. Local governments' purchases of external services, 1991-99

Per cent of operating costs

\begin{tabular}{lrrrrrr}
\hline & 1991 & 1993 & 1995 & 1997 & 1999 & $\begin{array}{r}\text { Change } \\
1991-99\end{array}$ \\
\cline { 2 - 6 } & & & & & & \\
Technical services and environment & 43.2 & 44.5 & 47.8 & 47.5 & 49.0 & 5.8 \\
Utilities & 10.6 & 16.2 & 17.2 & 17.6 & 16.9 & 6.3 \\
Roads & 39.2 & 40.8 & 42.8 & 38.6 & 38.7 & -0.5 \\
Education and culture & 5.8 & 5.4 & 5.4 & 5.7 & 5.9 & 0.1 \\
Hospital services & 4.0 & 4.1 & 3.8 & 4.1 & 4.9 & 0.9 \\
Social security and health & 3.9 & 3.3 & 3.8 & 4.1 & 4.4 & 0.5 \\
Administration & 16.0 & 17.0 & 17.4 & 17.8 & 18.6 & 2.6 \\
& & & & & & \\
Total & 9.1 & 9.3 & 9.8 & 9.8 & 10.1 & 1.0 \\
\hline
\end{tabular}

Source: Konkurrencestyrelsen (2001).

46. Where contracting out has been used, experience on changes in quality and price effects has been mixed. Available information suggest that cost reductions of some 15 to 25 per cent have often been achieved, although with experience spanning a greater interval. These effects are not extendable to all public service provision, as the most promising projects are likely to have been the ones first outsourced. Moreover, the possibilities of establishing a competitive private market may be limited in some areas, thereby reducing or eliminating the potential gains. Also, there are some examples that the quality of services outsourced has not met the expectations. The existing disparity across municipalities may serve as the starting point for assessing the magnitude of the macro-level savings potential from a consistent use of outsourcing. If all municipalities contracted out at the same scale as the most active already do, services worth an additional DKr 6 billion would be exposed to competition (Konkurrencestyrelsen, 2001). Assuming, hypothetically, a 20 per cent average cost reduction, this might imply modest total savings of some DKr 11/4 billion (0.1 per cent of GDP). This illustrates that if more significant reductions of public spending are to be achieved, contracting out needs to be applied much more widely than at present. This should both involve a more intensive use of the instrument within the existing legal framework and allowing private provision for a broader range of services.

47. A number of economic, political and institutional barriers need to be overcome if this is to take place. For example, the existing municipal structure is likely to impede the diffusion of outsourcing due to diseconomies of scale and the inherent fragmentation of the decision process. The latter is likely to discourage potential suppliers, as it takes a certain market size and some minimum security for the investment and development costs to pay off. This, in turn, could reduce the first-mover advantages for those municipalities that consider scaling up the use of outsourcing, thereby delaying the build-up of competitive markets. While this would seem to warrant adjustments of the municipal structure, this is not likely to come about by itself, at least in the near term. Therefore, political attention to address the problem is called for. One way of moving ahead might be to try to find ways of encouraging greater inter-municipal co-operation, for example, by extending the use of inter-municipal purchasing agencies and joint administrative systems. Imposing regular tendering for some services might also be considered. 


\section{User charges}

48. The term user charges is employed here in a broad sense. Most importantly, it designates situations where individual consumers or companies contribute directly with payment for services provided or funded by the public sector. However, it is also taken to include collective, private co-payment arrangements — such as private insurance schemes - even if these only directly link individuals' consumption and payment when a part-charge is levied for services. ${ }^{24}$ As a general policy instrument, user charges have a number of advantages.

- They may curtail demand and, therefore, public expenditure. User charges provide information to consumers and officials about the demand for, and costs of, providing services. The provision of public services free of charge obviously risks prompting excessive demand as the social costs of supplying them are largely irrelevant for the individual consumer's behaviour. ${ }^{25}$

- They result in an allocation of funds determined directly by the demand of consumers instead of being expressed indirectly through the political process and by the electorate as a whole.

- They provide an alternative to tax financing or mandatory social security contributions. Unlike user charges, tax financing redistributes income and consumption possibilities. Likewise, taxes reduce individuals' returns to work, save and invest in their human capital while user charges do not.

- As consumers are likely to pay more attention to the quality of services for which they pay, user charges may well prompt demand-side pressure for better outcomes, thereby furthering supply-side efficiency. This effect is probably reinforced if, at the same time, consumers have some scope for choosing between different providers.

49. In recent decades, there has been virtually no introduction of co-payment in new areas or increased co-payment in areas where it already existed. On the contrary, existing user charges have generally been lowered, for example for childcare and practical home help. Nevertheless, the share of private co-payment of publicly provided services increased from 5.9 per cent of total costs in 1977 to 13 per cent in 1997. The most distinct increase - particularly in the latter half of the period - was for education, health and social services (Finansministeriet, 2000b). The increase is attributable to the fact that spending rose most on services that had above-average levels of user charges in the 1970s, notably childcare and pharmaceuticals.

50. Danish policymakers have been distinctly reluctant to deal with the issue of user charges, let alone develop a coherent strategy for their application. In particular, introducing user charges in new areas has been controversial, not least on distributional grounds (see Box 2). The current mixture may best be seen as the accidental inheritance of the past. No attempts have been made to assess whether private co-payment is used where it makes most sense economically or whether the split between user financing and collective financing is appropriate. Randomness, more than absence of user financing, characterises current policies. Thus, sizeable user charges exist for some services such as childcare, dental care and

24. For private co-payment to impinge on demand it should be linked to individuals' marginal consumption. Payment arrangements already apply to number of services (for example, waste disposal, wastewater treatment and radio and television broadcasting) where users collectively finance (a part of) the costs for providing the services, but where the individual user's payment is independent of actual consumption.

25. Winter and Moutizen (2001) demonstrate that just giving information to consumers about the true costs of providing public services prompts a reduction of demand. 
pharmaceuticals. In the last two areas, total private co-payments are in practice high by international standards, as there is no ceiling on individuals' total payment. ${ }^{26}$ On the other hand, Denmark is distinctive for having virtually no private co-payment for primary and secondary health care, elderly care and tertiary education (Table 6) ${ }^{27} \mathrm{~A}$ range of non-core services for which demand is likely to be sensitive to the price, for example general adult education, vocational training and public libraries, are also provided with little or no user payment.

\section{Box 2. Distributional effects of user and tax financing of additional spending}

An increase in user charges for existing services would typically widen the dispersion of total consumption possibilities, although in principle this depends on how the extra revenue is used. Per capita public consumption declines with rising income (Finansministeriet, 2000c). Therefore, increasing user charges on the "average public consumption bundle" would be relatively more burdensome for low income households and even if the revenue is channelled back as a lump sum tax cut they would have a net reduction of consumption, while the opposite would be the case for high income households. Even so, the "loss of equality" should be balanced against the mitigation of overall static distortions and the potential favourable dynamic effects.

Moreover, the relevant weighting is different at the margin, when considering the mode of financing for new or higher quality services. In this situation user charges would not cause less redistribution but merely an increase in the "price" of private consumption. In contrast, tax financing would increase redistribution but at the cost of greater distortion of incentives to work, save and acquire human capital. Finally, even if discretionary measures are not taken to broaden user charges, this may evolve endogenously if private insurance schemes spread in areas such as hospital treatment or elderly care. As much as politically decided charges, this could challenge the principle of "free and equal access" in the future.

51. Developing a coherent strategy for the application of user charges would most likely include a broadening of their use and allowing local governments more discretion in setting their levels. It is difficult to judge a priori the extent to which an increase in the overall scope of user charges is warranted, although the higher share of public finances applied to overall consumption than elsewhere indicates a potential for a wider scope of user payments. Equity considerations, distortionary effects associated with the alternative of tax financing, and a careful evaluation of price sensitivities would be three of the elements entering this assessment. While a more consistent overall approach to user payment is paramount, examples of more specific changes for consideration would comprise the following (see also Annex IV):

26. OECD's health database suggests that the share of private co-payment in total health expenditure is slightly above the average level in other EU countries (but lower than in, for example, the United States and Canada), despite the fact that there are charges are in place only for pharmaceuticals and dental care.

27. Cross-country comparisons of the levels of user charges, especially aggregate payments, should be interpreted with caution. For example, the level and the marginal properties of private co-payment arrangements may be blurred if they are offset by reimbursement arrangements or if private insurance schemes enjoy preferential tax treatment. 
ECO/WKP(2002)6

Table 6. User charges for various personal services

Private co-payment percentage except as noted

\begin{tabular}{|c|c|c|c|c|c|c|c|c|c|}
\hline & \multicolumn{2}{|c|}{ Elderly care } & \multicolumn{2}{|c|}{ Childcare } & \multicolumn{4}{|c|}{ Healthcare services } & \multirow[b]{2}{*}{$\begin{array}{r}\text { Tertiary } \\
\text { education }\end{array}$} \\
\hline & Home help & $\begin{array}{c}\text { Institutional } \\
\text { accommodation }\end{array}$ & Aged $0-3^{1}$ & Aged $3-6^{2}$ & $\begin{array}{l}\text { In-patient } \\
\text { acute care }\end{array}$ & $\begin{array}{l}\text { Out-patient } \\
\text { medical care }\end{array}$ & $\begin{array}{l}\text { Pharma- } \\
\text { ceuticals }\end{array}$ & $\begin{array}{c}\text { General practitioner } \\
\text { office visit }^{3}\end{array}$ & \\
\hline Denmark & $\mathbf{0}$ & 5 & 33 & 33 & $\mathbf{0}$ & 5 & 43 & $\mathbf{0}$ & 3 \\
\hline Sweden & 6 & 8 & 20 & 0 & 2 & 27 & 29 & 15 & 11 \\
\hline Norway & - & - & $28-45$ & $28-5$ & 0 & - & 42 & 14 & 6 \\
\hline Finland & 14 & 20 & $10-15$ & $10-15$ & 8 & 23 & 52 & - & - \\
\hline Germany & - & $<25$ & $16-20$ & - & 2 & 10 & 52 & - & 8 \\
\hline France & - & - & 23 & 0 & 8 & 43 & 46 & - & 10 \\
\hline United Kingdom & 7 & 27 & $30-60$ & 0 & 1 & 12 & 10 & - & 25 \\
\hline Italy & - & - & 36 & 0 & 15 & 28 & 35 & - & 19 \\
\hline Netherlands & 10 & $10-39^{5}$ & 44 & 0 & 19 & 37 & 36 & - & 4 \\
\hline Austria & - & - & - & - & 10 & 20 & 50 & - & 1 \\
\hline Portugal & - & - & 11 & 0 & - & - & - & - & 8 \\
\hline Canada & - & - & - & - & 10 & 41 & 57 & 26 & 17 \\
\hline United States & - & - & 60 & 60 & 45 & - & 75 & - & 48 \\
\hline New Zealand & - & - & - & - & 8 & 53 & 35 & - & - \\
\hline
\end{tabular}

1. In most countries, user charges vary with family income. Where a range is not specified, the figures reported in the table are maximum charges for Denmark and Sweden and average charges for other countries except Australia and Portugal where they refer to the percentage of disposable income. In Finland, charges are subject to a ceiling.

2. In countries with no charges, the services in question are part of the education system and are typically part-time. In Australia, the Netherlands and the United Kingdom pre-primary education is free from 4 years and in Sweden from 5 years.

3. US dollars at 1998 exchange rates.

4. The figures show the share of private funds in financing educational institutions. Data refer to 1998 and are net of public subsidies.

5. 10 per cent in nursing homes and 39 per cent in residential homes.

Source: OECD Health Data Base 2000, OECD (2001a); Rostgaard and Fridberg (1998). 
- While parental payments for childcare are not especially low in a cross-country context, they are inappropriate inasmuch as they are not linked to the individual child's actual attendance. Redesigning user charges by relating them to marginal consumption could possibly facilitate a reduction of excessive demand but would need to be balanced against potential negative labour supply effects.

- Denmark is distinct in not having any user charges for elderly care. Current trends suggest that the pressure on supply-side rationing is considerable as "demand" for free services is booming. Introducing partial user payment, in combination with more extensive client choice and competition, is warranted in this area, and it is worth considering abandoning public subsidies for some practical services, such as cleaning.

- The substantial subsidies for adult and vocational education appear difficult to justify on grounds of economic externalities or equity concerns. Sizeable user charges should be introduced in this area, thereby shifting the costs back to the employers.

52. An issue that has been debated recently is whether it would be fruitful to distinguish between basic public services financed through taxes and supplementary services, which the public sector could provide against full user payment. ${ }^{28}$ This has been suggested as a way of forestalling demand pressures from eventually manifesting themselves in higher tax rates. While this might indeed alleviate pressures in some areas, in general publicly provided supplementary services should be used with caution. The implied increase in public sector production could in practice compromise policies of encouraging contracting out and might easily risk crowding out private sector production. A better way would be to expand outsourcing and client choice, in which case supplementary services would be purchased from a private provider.

\section{Client choice and vouchers}

53. While consumer choice is a fundamental characteristic of private consumption, there is typically more limited or no scope for users of public services to choose between providers or to influence their content; obviously, this reflects the zero or very low payments involved. The extent to which the limited choice impinges on perceived service quality is likely to vary across consumers and with the nature of the services in question; if proximity to the provider is considered of dominant importance, local monopoly-like supply conditions may prevail in any circumstance. Nonetheless, the authorities have long recognised that having a choice is often valuable in itself and assumed that users will increasingly demand tailored services and greater possibility to choose in the future (Kommunernes Landsforening et al., 1999 and Indenrigsministeriet, 2000). Indeed, client choice and influence has increased in scope over the past decade, for example via a legal right to choose hospital treatment outside the county of residence. Limited geographical choice has also been introduced for childcare, and a few municipalities have introduced voucher models for home help services. As discussed above, the government has stated its intention to greatly widen the scope for client choice in the areas of elderly care and secondary health care. Within primary education there is a long-standing tradition for private schools. These are entitled to a per student subsidy of 85 per cent of the municipalities' costs and have increased their market share slightly over the 1990 s to some 10 per cent.

54. While a comprehensive review of the current extent of user choice and the scope for increasing it within existing framework is beyond the remit of this chapter, the concept itself has some important bearings on expenditure policies. On the one hand, client choice, for example in the form of vouchers, is

28. Supplementary services might include longer opening hours in childcare institutions, single rooms in hospitals, better standard accommodation in nursing homes or additional home help services. 
likely to have some desirable effects. Surveys corroborate the view that user satisfaction and perceived quality tend to increase with the scope of choice. In addition, unless capacity constraints severely restrict client choice, it may facilitate competition among providers, thereby furthering efficient resource allocation. Client choice and vouchers may increase transparency in the decision making process by making the costs and trade-offs more visible to clients and policy makers. Finally, vouchers could make it easier for consumers to purchase supplementary services from their provider, thereby potentially helping to mitigate demand pressures at the margin. On the other hand, unrestricted client choice would often be difficult to reconcile with overall expenditure control, especially for services provided free of charge. The experience in 1997 and 1998 in the area of adult education was a forceful demonstration of these shortcomings; demand and public spending surged in response to abandoning budget envelopes and introducing extensive client choice accompanied by only negligible user co-payment. Thus, budget envelopes and rationing through assessment of need are often unavoidable instruments for safeguarding the control over total spending, but this does not preclude the above advantages from manifesting themselves.

55. The two areas in which the government is extending client choice - elderly care and secondary health care - are both characterised by not having any (imminent) upper limit to demand. The budgetary risk of client choice in those two sectors could, therefore, be large; while the assessment-of-need rationing limits the risk in the case of elderly care there would be no efficient constraints on health spending if the budget envelopes are not maintained. In contrast, for services with virtually unrestricted access, such as childcare and ordinary education, there is typically little risk that client choice would prompt an unsustainable demand response, and the instrument would be particularly suitable in these areas. Indeed, the use of vouchers in OECD countries is most common in the education sector (Cave, 2001). While more widespread but careful use of the instrument is warranted, the fragmented municipal structure may be an impediment to initiating such a process.

\section{Enhancing administrative efficiency}

56. Well-designed public management policies are likely to be important in furthering good performance, i.e. encouraging high productivity and ensuring that stated policy objectives are reached efficiently. However, measuring public sector productivity and goal achievement at the aggregate level is notoriously difficult. Therefore, while this section provides a brief overview of current trends in public management policies, it contains no attempt to quantify their effects on macroeconomic performance.

\section{Promoting good performance}

57. Danish public management policies have changed considerably over the most recent decade, notably at the national level. The main thread has been a wish to link appropriations, jobs and pay more closely to performance, thereby enhancing overall productivity. For example, company-style accounting by state enterprises and agencies spread considerably over the 1990s. The same is true for performance-related contracts with public authorities and their directors, which virtually did not exist 10 years ago. Contracts are used at two levels. Performance-related contracts are signed within individual ministries between the department and its agencies. Also, performance-pay contracts can be signed with directors of individual government agencies. In 2000, around half of all government agencies had signed contracts, while the equivalent share for directors of government agencies was around a quarter. Both types of contracts have increased significantly in number in recent years (Table 7). The performance criteria in the contracts vary. For directors' contracts ex post performance is quantified on a scale from 0 to 100. The average score in 1999 was 67 per cent. 
Table 7. The prevalence of performance-related contracts in central government Number of contracts

\begin{tabular}{lrrrrrrrrr}
\hline & 1992 & 1993 & 1994 & 1995 & 1996 & 1997 & 1998 & 1999 & 2000 \\
\cline { 2 - 9 } & & & & & & & & & \\
Contracts at the institutional level & 9 & 15 & 20 & 27 & 31 & 38 & 56 & 81 & 83 \\
Managers'contracts & - & - & - & 5 & 12 & 21 & 35 & 40 & 48 \\
\hline
\end{tabular}

Source: Ministry of Finance.

58. The use of fixed-term employment contracts has been scaled up significantly, while "life-time" civil-service jobs are used less frequently, thereby increasing overall flexibility. At present, some 15 per cent of public-sector managers are employed on a fixed-term basis; the typical duration is three to five years with a common pay supplement of 15 to 25 per cent. Finally, a wage reform was introduced in the late 1990s that will gradually weaken seniority-based wage elements and make wage-setting more individualised.

59. Developing a consistent policy for evaluation of government activities should be a priority. Ideally, this should include overall goal-achievement within policy areas, the quality of services provided and the efficiency of individual government institutions or entities. Such evaluation can help identifying non-performing units as well as best practices. Applying a broad definition, evaluation currently takes place at several levels; it is conducted by numerous actors; and the nature of the evaluation can take many different forms. Thus, it covers a wide field from appropriation control conducted by the National Audit Agency through outcome and efficiency analysis by sector-specific evaluation centres to scientific research and analysis by private consulting companies ordered by public-sector entities. A few defining characteristics and tendencies may be worth mentioning:

- Total evaluation activity seems to be increasing. This is likely to reflect, in part, the aforementioned sharper focus on public management policies with the Ministry of Finance as the main driver. In addition, the traditional conflict of interest between spending advocates and budget advocates has increasingly developed into a competition between analytically based arguments, which has prompted an increase in the use of analysis of efficiency, policy effects and outcomes on both sides.

- The central government has involved itself more directly in policy areas where counties and municipalities are formally responsible. This manifests itself both in the outlining of policy objectives and in regulation (see above). In addition, the acceptance of local or regional variations in service standards has decreased amongst central-level policy makers. In continuing of these tendencies, policymakers at the central level have looked for ways to ensure that intended policies are pursued at lower levels of government and that resources are used efficiently. Evaluation lends itself well to this end. Independent evaluation agencies were established for the secondary health-care sector and education sector in 1999 under the Ministries of Health and Education, respectively.

60. Despite the increasing level of activity, there is still considerable scope for anchoring evaluations more closely and systematically in the budget process. In fact, current activities are not guided by an overall evaluation policy. Much of the ongoing effort is rather fragmented and detached from the political process. Without compromising the current diversity, developing a strategy for systematic use of cost-benefit analysis and evaluations as an integral part of the budget process is warranted. This could 
involve concentrating more resources under the auspices of a single independent agency that would have the capacity to strengthen the quality as well as the legitimacy of the analysis. A stronger attachment to the budget process could also be facilitated by a wider use of sunset clauses, making eventual extension of appropriations dependent in part on the result of evaluation.

\section{Digital administration}

61. Denmark is well placed to take advantage of ICT technology as a means to strengthen administrative efficiency in the public sector. Personal computer and internet penetration rates are amongst the highest in the world, and access to broadband is likely to increase rapidly in the near term. In addition, surveys suggest that there is considerable openness and interest in the population for using electronic self-service facilities through the internet. One obvious advantage from the consumers' point of view is the effective extension of opening hours. Self-service facilities are prevalent in many areas already, including, for example, submission of tax declarations, reservation and loan services in municipal libraries, booking services and access to all central government forms. A government portal for all business services is currently being developed.

62. While better supply of electronic self-service facilities is clearly to the advantage of citizens and firms, in themselves such facilities do not necessarily reduce the costs of public-sector administration and thereby promote efficiency. To achieve this end, changes in working procedures within individual public-sector entities and across organisational structures may be required. The government has recently launched a strategy for furthering digital administration in the public sector with the explicit objective of reducing administrative costs as much as possible (Kommunernes Landsforening et al., 2001). A task force has been set up to co-ordinate and lead the development of concrete initiatives. ${ }^{29}$ The focus on digital administration is motivated in large part by the fact that reaping the savings potential in this area will help make more resources available for providing personal services. The potential size of the savings will depend in part on the technologies that will become available, and no estimate thereof has been made. Instead, the strategy focuses on furthering changes in working procedures and improving the possibilities of electronic data exchange within and across government entities and between the public sector and its users. This is bound to be an ongoing process for an extended period of time, but with the existing Central Population Register (see Box 3), Denmark probably has a better starting point than many other countries.

\section{Box 3. The Central Population Register (CPR)}

The CPR register was established already in the late 1960s as a precondition for the introduction of the withholding tax in 1970. Similar registers were established around the same time in the other Scandinavian countries. The register identifies all persons resident in the country or holding Danish citizenship by a civil registration number.

This number is used as identification in virtually all public sector administrative systems and for all contacts between individuals and public authorities. Thus, when contacting a general practitioner, being hospitalised, enrolling children in school, applying for a social transfer, submitting a tax declaration or receiving elderly care, the civil registration number is always used in the individual's dossier. The number must also be stated to employers for their wage administration, and its presentation is a precondition for opening a bank account. Subject to the restrictions concerning privacy set in the CPR Act, this facilitates extensive exchange of data between public-sector authorities.

29. The task force has its own board of top civil servants. While located in the Ministry of Finance, officials from all tiers of government, including local governments, are present in the task force. 


\section{Summing up}

63. The primary policy issues that arise from the analysis in this chapter concern overall expenditure control in counties and municipalities and strengthening the role of competition and market signals in the provision of a wide range of public services. As most such services are provided by local governments, these issues are strongly interrelated. The fundamental question is whether the traditional policies of widespread local-government autonomy and "free and equal access" can be reconciled, in their present form, with effective expenditure control in the future.

64. The framework of formalised inter-governmental budget co-operation has not prevented an unplanned increase in local governments' income tax rates. The principal deficiency of the co-operative approach as it has worked out in practice is that it embodies no efficient mechanism to ensure that actions taken by individual counties and municipalities, when taken together, conform to the aggregate spending and tax levels envisaged in the agreements. In this sense, local government autonomy has prevailed at the expense of aggregate spending control. Adjustments to the budget co-operation framework should be a top priority and would need to involve restrictions on local governments' taxing powers. At the same time, there is a strong need to clarify responsibilities between the various levels of government. In some cases this would involve less micro-management by the central government.

65. More efficient resource allocation could be achieved by enhancing competitive structures in the provision of services as well as allowing a greater role for demand signals such as user charges and client choice. This is particularly relevant in the case of Denmark inasmuch as public consumption is a larger share of spending than elsewhere. One barrier impeding such reforms is the widespread perception amongst policymakers that these instruments conflict with distributional objectives. However, as has been argued in this chapter, this perception is at best partial and at worst misleading. Institutional barriers are important too. One factor is the fragmented policy decision process inherent in the decentralised government structure itself. Another is the fact that potential synergies from the simultaneous use of several instruments are difficult to reap because the authority to change policies does not always lie with the same level of government. While some of these barriers are difficult to overcome and involve trade-offs, they nevertheless deserve attention.

66. A summary of the recommendations that flow from the analysis in this chapter is contained in Table 8. 


\section{Table 8 . Summary of recommendations}

Recommendation

\section{Budget process}

Introduce politically binding expenditure ceiling.

Strengthen multi-annual budgeting procedures.

Link evaluations closer to the budget process.

\section{Local governments}

Improve spending control and compliance with agreements.

Clarify responsibilities between different levels of government and match with taxing powers.

Encourage greater efficiency in local governments.
The fiscal-stance measures currently guiding fiscal policies focus on the budget balance but do little to restrain expenditure growth. The existing ministerial expenditure ceilings put forward in the budget proposal in August are not binding in the following political negotiation process.

The current procedure of budgeting outlays in the three budget forecast years following the fiscal year are not fully consistent with medium term projections.

No overall evaluation policy is in place consistently assessing the performance and productivity of government agencies or the goal-achievement of government activities. Expenditure analyses are carried out within the ministries as an integrated part of the budget process. However, while evaluation activity in independent publicly-funded institutes is increasing, its impact on the budget process is limited.

Local governments have repeatedly exceeded agreed spending levels, and their income-tax rates have drifted up as a result. This compromises central government tax policies and has adverse impacts on labour supply.

By setting objectives and imposing regulation the central government has assumed de facto control in areas that have been devolved to local governments. This makes clear accountability more difficult.

Economies of scale warrant a certain minimum size of municipalities. Moreover, the fragmented political decision process risks impeding the spread of competitive structures.
A ceiling for total central-government expenditure, which is binding throughout the budget process, should be introduced. While determining its precise demarcation would warran further analysis, to be effective it would need to be set in nominal terms and include grants to local governments. Achieving political agreement on the overall spending level prior to the budget negotiations with the local governments would strengthen top-down control.

Improve the consistency with medium-term projections and use forecasting techniques to provide best possible projections of future expenditure.

Evaluation of performance and productivity developments in individual spending areas should be linked closer to the

budget process itself, possibly in tandem with a wider use of sunset clauses. Consideration should be given to concentrate more responsibility for evaluations with an independent body

Local governments' entitlement to set income-tax rates should be restricted, either through a centrally determined tax freeze or by imposing financial penalties on tax increases. To reconcile this with local-government autonomy, counties and municipalities could be allowed more discretion in setting property tax rates, the basic tax allowance and user charges. In policy areas where the central government wants to play a major role in setting service standards, it should take back the financing responsibility accordingly. On the other hand, where the central government does not want to reduce local governments' taxing powers, it should abstain from detailed regulation

Efforts to develop instruments encouraging inter-municipal co-operation, voluntary mergers and enhancing the role of market signals should be strengthened. 
ECO/WKP(2002)6

Table 8. Summary of recommendations (continued)

Recommendation

Strengthen competition and market signals

Encourage competition in the provision of publicly financed

services

Develop a coherent strategy for user charges.

Strengthen client choice to exploit synergies

\section{Administrative efficiency}

Broaden and deepen the use of performance-improving

instruments.

Strengthen digital administration.

Source: OECD.

Present situation

Elaboration

Compliance with the Ministry of Finance circular on tendering and outsourcing has been mediocre, and the trend rise in municipalities' use of these instruments has stalled.

User charges are at present a reflection of past traditions and are not, necessarily aligned with the price elasticities of demand. As a result they are not providing appropriate market signals.

Clients' choice has been furthered in some areas, but inadequacy of information, capacity constraints and politica reluctance continue to restrain its impact. The government has outlined a more comprehensive clients' choice programme.

Policies to promote efficiency such as performance contracting and performance-related pay has strengthened significantly.

Denmark is well placed to take advantage of ICT to improve the efficiency of public administration. A task force has been set up in the Ministry of Finance to push this ahead.
Encouraging competitive framework conditions is warranted for a wider range of services. Enforcement of existing provisions regarding central-government agencies' contracting out should be strengthened, and local governments should have more freedom and stronger incentives to establish competitive production structures. More effort should be devoted to identifying and removing barriers to outsourcing.

User charges should in general be designed so as to optimise the demand response. Higher or more well-designed charge seem appropriate in areas such as home help, childcare and adult and tertiary education. Local governments should be allowed more discretion in setting charges.

Clients' choice may often in itself raise the perceived quality of services. In addition, synergy effects may arise, as allowing clients to determine the prevailing providers could also foster greater competition. However, for services with no imminent level of satiation, a necessary balance needs to be struck between clients' choice and expenditure control. More client choice would often need to be accompanied by user charges.

There is still scope for improving implementation of such policies, particularly at lower levels of government.

Continue developing the strategy for e-government and ensure that savings are collected for centrally determined re-allocation. 


\section{BIBLIOGRAPHY}

Adema, W. (1999),

Net Social Expenditure, OECD Labour Market and Social Policy Occasional Papers, No. 39.

Adema, W. (2001),

Net Social Expenditure (2nd Edition), OECD Labour Market and Social Policy Occasional

Papers, No. 52.

Blom-Hansen, J. (1996),

"Kan budgetsamarbejdet mellem staten og kommunerne forbedres?", Nordisk Administrativt Tidsskrift 4/1996, 77, Årgang.

Blom-Hansen, J. (1998)

"Macroeconomic Control of Local Governments in Scandinavia: The Formative Years", Scandinavian Political Studies, Vol. 21, No. 2, 1998.

Blomquist, S. (1999),

"Dagis och drivkrafter", Finansdepartementet Ds 1999:67.

Cave, M. (2001),

"Voucher Programmes and Their Role in Distributing Public Services" in OECD Journal on Budgeting, Volume 1, No. 1.

Dansk Arbejdsgiverforening (2000),

Integration og arbejdsmarkedet.

Davidsen, S. and N.T. Hanus (2001),

"Analyse af det offentlige forbrug siden 1992”, Finansministeriet, arbejdspapir nr. 1/2001.

Det $\varnothing$ konomiske Råd (2000),

Dansk Økonomi, Forår 2000.

Finansministeriet (1999a),

Vejledning i udarbejdelse af samfundsøkonomiske konsekvensvurderinger.

Finansministeriet (1999b),

Budgetredegørelse 1999.

Finansministeriet $(2000 a)$,

"Borgernes tilfredshed med den offentlige sektor — baggrundsrapport",

www.fin.dk/udgivelser/publikationer.

Finansministeriet $(2000 b)$,

Redegørelse om brugerbetaling. 
ECO/WKP(2002)6

Finansministeriet $(2000 c)$,

Finansredegørelse 2000.

Finansministeriet (2000d),

Statens status og konteringsprincipper.

Finansministeriet (2001),

"Bugetredegørelse 2000/2001.

Gustafsson, S. and F. Stafford (1991),

"Child Care Subsidies and Labor Supply in Sweden", Journal of Human Resources, XXVII, 1.

Heinesen, Eskil (2000),

Local Public Choice of School Expenditure: A Dynamic Panel Data Model, AKF Forlaget.

Hofferth, S.L and D.A. Wissoker (1991),

"Price, Quality and Income in Child Care Choice", Journal of Human Resources, XXVII, 1.

Indeningsministeriet (1998),

"Fordelingen af opgaver i den offentlige sektor, Betænkning nr. 1366, Opgave-kommissionen.

Indeningsministeriet (2000),

Sammenlignelig brugerinformation, Betænkning nr. 1339 afgivet af arbejdsgruppen om

sammenlignelig brugerinformation.

Indeningsministeriet (2001),

"Der kommunale struktur. Størrelseseffekter i den kommunale sektor".

Jacobzone, S. (1999),

Ageing and Care for Frail Elderly Persons: An Overview of International Perspectives, OECD Labour Market and Social Policy Occasional Paper No. 38.

Jacobzone, S. (2000),

Pharmaceutical Policies in OECD Countries: Reconciling Social and Industrial Goals, OECD,

Labour Market and Social Policy Occasional Papers, No. 40.

Kommunernes Landsforening et al. (1999),

Friere valg på de kommunale sericeområder.

Kommunernes Landsforening et al. (2001),

Digital forvaltning, Joint report between the Ministry of Finance, the Ministry of Economic Affairs, the Ministry of the Interior, the Ministry of Business and Industry, the Ministry of ICT and Research, the Association of Municipalities, the Association of County Councils and the Municiaplities of Copenhagen and Frederiksberg.

Konkurrencestyrelsen (2001),

Konkurrenceredegørelse 2001.

Lotz, J. (1998),

"Forholdet mellem stat og kommuner- teori og praksis", in Nationaløkonomisk tidsskrift, Bd. 136. 
Lotz, J. (2001),

“Krise I det kommunale tilskuds- og udligningssystem?”, Samfundsøkonomen 2001/7.

Manning, W.G., J.P. Newhouse, N. Duan, E.B. Keeler, A. Leibfritz and M.S. Marquis (1987),

"Health Insurance and the Demand for Medical Care: Evidence from a Randomized

Experiment", American Economic Review, 77(5), pp. 251-77.

Ministry of Health (2001),

The Danish Health Care Sector in Figures - 2000/2001.

Ministry of the Interior (1999),

Municipalities and Counties in Denmark - Tasks and Finance.

Mourizen, P.E. (1999),

De små kommuner. De er ikk' så ringe ennda?, AKF Forlaget.

Oates, W.E. (1990),

"Fiscal Federalism: An Overview", in R. Prud'homme (ed.), Public Finance with Several Levels of Government, Proceedings of the $46^{\text {th }}$ Congress of the International Institute of Public Finance, Brussels.

OECD (1999),

Taxing Powers of State and Local Government, OECD Tax Policy Studies, No. 1, Paris.

$\operatorname{OECD}(2000)$,

"Economic Survey of Denmark", Paris.

OECD (2001a),

Economic Outlook No. 70, Paris.

$\operatorname{OECD}(2001 b)$,

Starting Strong: Early Childhood Education and Care, Paris.

OECD (2001c),

Knowledge and Skills for Life, First results from PISA 2000.

OECD (2001d),

Education at a Glance: OECD Indicators 2001 Edition, Paris.

Pedersen, K.M., J. Clausen, J.G. Christensen, B.H. Fogh, J.K. Gøtrik, O.P. Kristenen, P. Riis and C. Sørensen (1995),

Et bedre sundhedsvæsen - men hvordan?, Lægeforeningens Forlag.

Pedersen, K.M. (1999),

"Det danske sundhedsvæsen i perspektiv", in T. Christiansen (ed.), International vurdering af organisation og finansiering af det danske sundhedsvæsen, Odense Universitetsforlag.

Regeringen (2001),

Redegørelse om offentlige investeringer. 
Rattsø, J. and P. Tovmo (1997),

"Local Government Responses to Shocks in Denmark", in Kommunal Budgetoversigt, Finansministeriet, Januar 1998.

Rostgaard, T. and T. Fridberg (1998),

Caring for Children and Older People - A Comparison of European Policies and Practices, Social Security in Europe 6, The Danish National Institute of Social Research 98:20.

Skolverket (1999),

Avgifter i förskola och fritidshem 1999, Skolverkets rapport 174.

Udliciteringrådet (2000),

Ministeriernes anvendelse af udbud og udlicitering.

Winter, S. and P.E. Mouritzen (2001),

"Why People Want Something for Nothing: The Role of Asymmetrical Illusions", European Journal of Political Research 39, pp. 109-143. 
ECO/WKP(2002)6

\section{ANNEX I}

\section{PUBLIC EXPENDITURE IN PERSPECTIVE}

1. With a view to identifying the key factual characteristics of Danish public expenditure, this Annex provides a brief overview of historical trends in public expenditure and a cross-country comparison of the current level and structure of public spending.

\section{The historical evolution}

2. The unsuccessful economic policy in the decade following the 1973/74 oil crisis caused total public expenditure to surge from just over 40 per cent of GDP to almost 60 per cent between 1973 and 1982. With some cyclical fluctuation, this high level persisted until the mid-1990s, before declining considerably over the most recent seven years (see Figure 1 in the main text).

3. The expansion of the public sector and of social welfare spending was not fully planned, but resulted, in part, from a process where new or better-standard services and transfer schemes turned out to be more expensive ex post than had been envisaged. ${ }^{1}$ Public consumption rose by an average of 3.4 per cent annually in constant prices from 1973 to 1982 (compared with GDP growth of 1.3 per cent) and jumped from 23 per cent of GDP to 29 over this period. At the same time, social transfers increased from 10 to 17 per cent of GDP; this was the combined result of rising unemployment, easier eligibility criteria for early retirement pension in particular and more generous benefit levels in general. The interrelated declines in public investment activity and subsidies offset only a small part of the surge in public consumption and social transfers. Moreover, as taxes were not raised in line with the higher levels of primary spending, a large fiscal deficit occurred at a time when real and nominal interest rates rose to post-war peak levels. The upshot was a marked jump in interest payments, which rose by some 6 to 7 percentage points of GDP.

4. The difficult experience of the 1970s helped, eventually, to bring about greater political consciousness of the importance of overall expenditure control and management. The years from 1982 to 1986 were a period of considerable fiscal consolidation. Real public consumption was restrained, benefit levels were held nominally unchanged, and public-sector investment continued to shrink. At the same time, output grew vigorously, supported primarily by rapidly declining interest rates (following the introduction of the fixed-exchange-rate regime in 1982) and deregulation of capital markets and the financial sector. Total public expenditure fell from 59 per cent of GDP in 1983 to $53^{1 / 2}$ per cent in 1986. However, these gains were gradually eroded in the subsequent protracted period of weak growth up to 1993, when the

1. Two examples may serve to illustrate this. First, a classic ministerial report from 1973 (Perspektivplan II) provided scenarios for the possible evolution of the public sector 15 years ahead but failed - even in its fastest growing scenario - to envisage the strength of the subsequent actual expansion. Second, when the early retirement benefit scheme was introduced in 1979, the number of beneficiaries was not expected to exceed 1 per cent of total employment. However, it rose rapidly to above 5 per cent and stands at 7 per cent today. 
expenditure-to-GDP ratio once again ratcheted up towards 60 per cent. ${ }^{2}$ This was mainly the result of unemployment rising to new highs and considerable inflow into other transfer schemes as well. These trends reversed again in the second half of the 1990s, when unemployment fell to the lowest level since the mid-1970s. By 2000, the public-expenditure-to-GDP ratio had returned to its 1980 level.

\section{The public sector's relative price and cost developments}

One of the factors influencing the evolution of the overall expenditure-to-GDP ratio is price and cost developments in the public sector relative to those of the private sector. The public consumption deflator is likely to increase faster than the GDP deflator, at least in the long term. In part, this is due to the conventional problems of measuring public-sector productivity increases in the national accounts. Therefore, the deflator of public-sector production is measured on a cost basis and mainly follows wage increases. This implies a systematic upward bias in the deflator and an offsetting downward bias in the volume increases. Even so, the true - unmeasured - trend growth rate in public-sector productivity is generally accepted to be lower than the economy-wide trend productivity growth rate. This is because public-sector production is more labour intensive than production in the private sector, and the scope for technology-induced productivity increases lower. If at the same time public-sector wages increase in parallel with those in the private sector, this will cause even correctly measured unit labour costs to grow faster in the public sector than for the economy as a whole (Baumol's disease). All else being equal, this would imply a higher trend increase in the public consumption deflator than in the GDP deflator, thereby putting upward pressure on expenditure and taxes.

However, the actual evolution of the relative price of public consumption over the past 25 years does not, at first glance, conform to this hypothesis. While it did indeed increase rapidly up to the mid-1970s, it has mostly hovered around a constant level since then (Figure A1). This seems to have different explanations in the 15 years up to around 1990 and in the subsequent decade. Disregarding short-term fluctuations, unit labour costs in the public and the private sector increased at broadly the same rate between 1975 and 1990; the higher (measured) productivity growth in the private sector was offset in this period by lower nominal wage increases in the public sector. Against this background, it is not surprising that the deflators of public consumption and GDP also rose in parallel.

In contrast, during the 1990s the public sector's relative unit labour costs resumed the upward trajectory that would be expected to be the normal pattern. Two factors help to explain why the relative price of public consumption has nonetheless remained constant over the past decade. First, the rise in the relative unit labour costs did not manifest itself fully in the public sector's relative output price. This is attributable to the fact that the private sector's wage share declined, thereby causing output prices - and thus the GDP deflator - to increase faster than unit labour costs. Second, the deflator for non-wage public consumption declined significantly over the 1990s relative to the GDP deflator. These factors are probably of a temporary nature; the private sector's wage share is bound to stabilise sooner or later, and it is unrealistic to expect the relative price of non-wage public consumption to keep declining at the speed it has done in the past decade. If so — and if relative unit labour costs in the public sector continue to increase - the likelihood is that the public consumption deflator will increase more rapidly than the GDP deflator in the future, in contrast with recent developments.

\section{An international comparison}

5. Gross social outlays are significantly higher in Denmark than in the Anglo-Saxon and the Southern European countries (Table A1). In contrast, they are not particularly high when compared with the EU average, and slightly lower than in Germany, France and Italy. However, this simple comparison of gross social outlays is subject to a number of caveats:

2. The expenditure-to-GDP ratio continued to rise in 1994, when it exceeded 60 per cent. However, this was largely due to the fact that social pensions and social assistance were made taxable as from that year in order to strengthen the transparency of the transfer system. The move to higher but taxable pensions and social assistance benefits was neutral to the budget balance but raised both tax- and expenditure-to-GDP ratios by 1.9 percentage points. 
- Transfers are subject to the same tax treatment as wage income in Denmark and several other countries, while they are predominantly untaxed in some countries. It is the net-of-tax value, which impinges on the amount of redistribution from workers to non-workers, even if it is the marginal tax rates that affects incentives.

- Indirect taxes are higher in Denmark than in most other countries, the VAT rate being 25 per cent and the base having few exemptions. Indirect taxes reduce the purchasing power value of social benefits. Therefore, as effective indirect tax rates vary across countries, comparing gross benefits without adjusting for the higher price level may be misleading.

Figure A1. Relative price and cost developments in the public sector $1972=1^{1}$
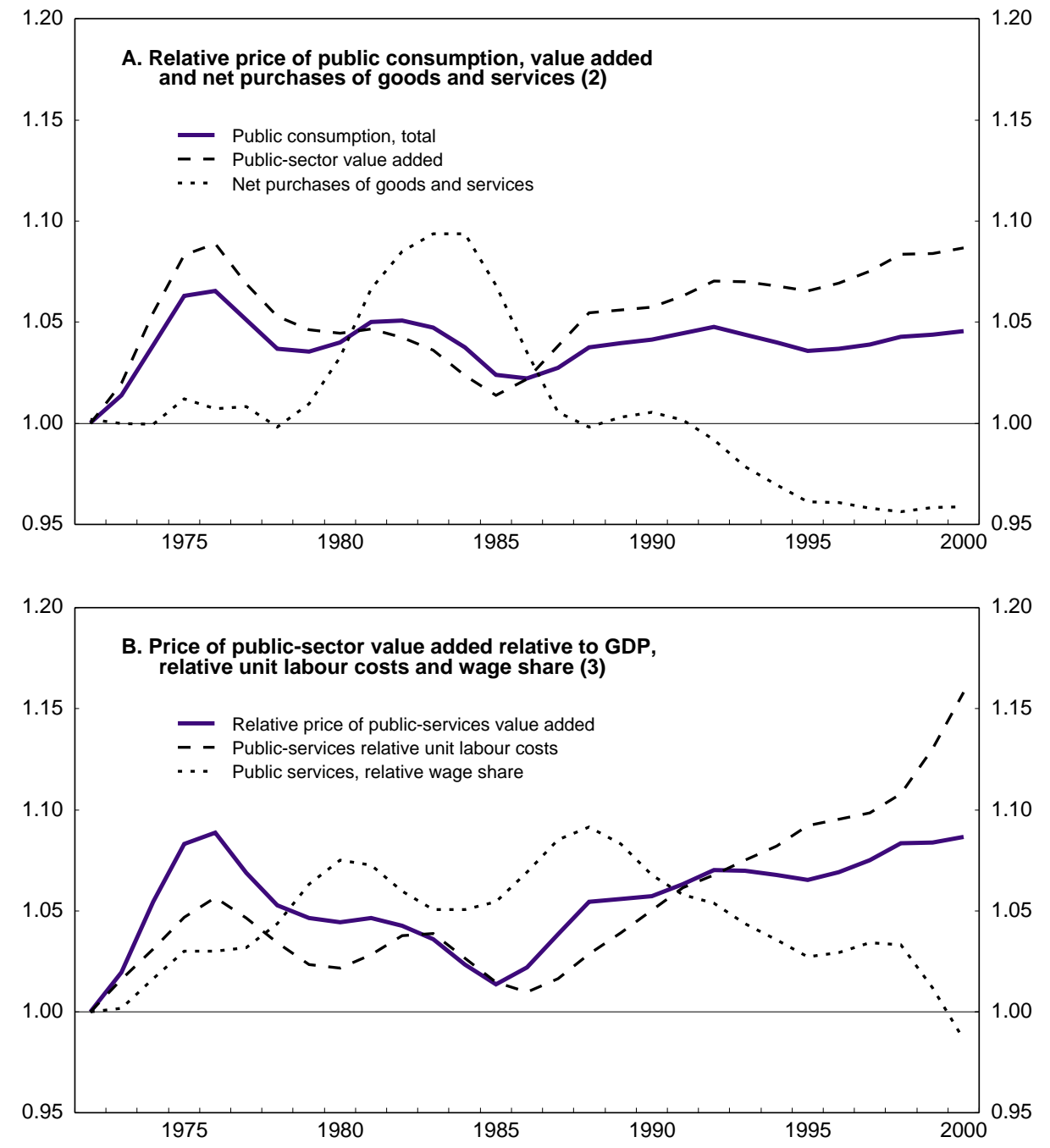

1. All series are three-year centred moving averages.

2. National accounts deflators for the respective series relative to the GDP deflator.

3. The relative wage share is inverted, i.e. it is the economy-wide wage share over the public sector's wage share. The change in the relative price of public-sector value added is approximately the sum of the changes in relative unit labour costs and the inverse relative wage share.

Source: Statistics Denmark; OECD. 
- The collective economic support of individuals (or specific types of production) need not be accounted for on the expenditure side of the budget but may instead take the form of tax breaks for social purposes (TBSPs). Economic support of families with children, which exists in virtually all OECD countries, provides an example. While some countries (for example Denmark, Sweden and Norway) have child benefit schemes that appear on the expenditure side, other countries (for example, France, Germany, Italy and Ireland) give tax allowances to families with children.

- Governments can impose social expenditures on private-sector entities through legislation. Such mandatory private social benefits include employer payments to employees absent from work due to sickness and the financial value of employment protection legislation (EPL), for example severance pay and notice periods.

Table A1. The structure of public expenditures in selected OECD countries, 2000 Per cent of GDP

\begin{tabular}{|c|c|c|c|c|c|c|c|c|c|}
\hline & \multicolumn{6}{|c|}{ Current expenditure } & \multicolumn{3}{|c|}{ Net capital expenditure } \\
\hline & Consumption & $\begin{array}{c}\text { Social } \\
\text { security } \\
\text { payments }\end{array}$ & $\begin{array}{c}\text { Other } \\
\text { current } \\
\text { transfers }\end{array}$ & Subsidies & $\begin{array}{l}\text { Property } \\
\text { income }\end{array}$ & $\begin{array}{c}\text { Total } \\
\text { current } \\
\text { expenditure }\end{array}$ & $\begin{array}{c}\text { Net } \\
\text { investment }\end{array}$ & $\begin{array}{l}\text { Other net } \\
\text { capital } \\
\text { outlays }\end{array}$ & $\begin{array}{l}\text { Total public } \\
\text { expenditure }\end{array}$ \\
\hline Sweden & 26.6 & 18.9 & 1.9 & 2.0 & 5.4 & 54.7 & 0.5 & -0.1 & 55.2 \\
\hline Denmark & 25.5 & 17.5 & 2.5 & 2.3 & 4.6 & 52.4 & -0.4 & -0.2 & 51.8 \\
\hline France & 23.7 & 18.4 & 1.7 & 1.3 & 3.3 & 48.4 & 2.9 & 0.8 & 52.1 \\
\hline Greece & 15.0 & 15.8 & 8.5 & 0.2 & 8.8 & 48.3 & 4.1 & -0.3 & 52.0 \\
\hline Austria & 19.8 & 18.7 & 2.6 & 2.6 & 3.5 & 47.3 & 0.3 & 1.8 & 49.4 \\
\hline Belgium & 21.4 & 14.7 & 2.2 & 1.5 & 7.2 & 46.9 & 0.2 & 0.8 & 47.9 \\
\hline Finland & 21.5 & 13.3 & 6.8 & 1.6 & 3.1 & 46.3 & 0.5 & 0.0 & 46.8 \\
\hline Germany & 19.0 & 18.9 & 1.6 & 1.7 & 3.5 & 44.8 & 0.2 & 0.9 & 45.9 \\
\hline Italy & 18.1 & 17.2 & 1.3 & 1.2 & 6.8 & 44.6 & 1.2 & 0.9 & 46.7 \\
\hline Norway & 21.2 & 15.5 & 2.3 & 2.8 & 2.1 & 43.9 & 2.0 & 0.3 & 46.2 \\
\hline Netherlands & 22.8 & 12.5 & 1.4 & 1.6 & 4.4 & 42.7 & 0.5 & -0.4 & 42.7 \\
\hline Japan & 16.1 & 9.8 & 9.7 & 0.8 & 3.5 & 39.9 & 3.5 & 1.2 & 44.6 \\
\hline Portugal & 20.0 & 11.8 & 2.5 & 1.0 & 3.2 & 38.6 & 2.2 & 0.1 & 40.9 \\
\hline United Kingdom & 18.5 & 13.5 & 2.2 & 0.6 & 3.0 & 37.8 & 1.1 & 0.3 & 39.2 \\
\hline Spain & 16.9 & 12.4 & 1.3 & 1.2 & 3.6 & 35.5 & 3.3 & 0.7 & 39.4 \\
\hline United States & 14.3 & 10.7 & 0.0 & 0.3 & 3.8 & 29.1 & 1.2 & -0.3 & 30.0 \\
\hline Ireland & 14.1 & 9.8 & 0.0 & 1.0 & 2.5 & 27.4 & 2.5 & 2.9 & 32.8 \\
\hline
\end{tabular}

Note: The countries are ranked in descending order according to their total current expenditure ratio. Source: OECD.

6. The OECD's work on net social expenditures (Adema, 1999 and 2001) seeks to address some of these problems in the area of social expenditures. Comparing gross and net social expenditures clearly demonstrates that accounting for the above mentioned factors can significantly alter the cross-country ranking of public expenditure levels. In general, net publicly mandated social expenditures vary much less across countries than do gross public expenditures. In 1997, Denmark had the highest level of gross public social expenditures amongst the 17 countries analysed. However, net publicly mandated expenditure in Denmark was below the levels in Belgium, Germany and Sweden and only moderately higher than in Finland, Italy and Norway (Table A2). Moreover, while net publicly mandated social expenditure to GDP was still 7 to 10 percentage points higher than in countries such as Australia, Canada, Ireland, New Zealand and the United States, the differences were considerably smaller than for gross social expenditure. 
A number of arguments would support that the much smaller gap between Denmark and other countries in net than in gross social expenditure is a result extendable to total public spending: ${ }^{3}$

- First, the distinction between net and gross social expenditure is of little importance to most other non-social budget components, and Denmark's gross spending on these is comparable to the levels elsewhere.

- Second, the adjustment for mandatory private social expenditures is probably incomplete in its treatment of the financial value of EPL. As the Danish EPL regime is closer to the liberal provisions of the Anglo-Saxon countries than to the stringent rules in most European countries, this might — all else being equal — tend to underestimate the "true" level of expenditure in the latter group of countries. However, there is no simple way to assess employees' financial value of, for example, long notice periods.

- Third, tax advantages to married people are not considered TBSPs but rather an inherent feature of some countries' tax systems. Such tax advantages are virtually non-existing in Denmark, but tangible in, for example, Ireland, the United Kingdom, Italy, France and Germany. If the purpose were to assess net total public expenditure, it would be natural to adjust for such tax advantages, and doing so would most likely tend to lower Denmark's relative expenditure level.

7. It should be noted, though, that most countries' transfer systems are less redistributive (even if the resulting outlays are recorded as social spending) than Denmark's. This is due to the fact that the Danish system is basically a flat rate system in contrast to the earnings related social security systems that dominate elsewhere.

3. It should be emphasised that this does not in itself imply anything about the severeness of overall distortions of incentives to work and educate in Denmark relative to other countries. This should be assessed on the basis of marginal tax rates and how public spending is channelled back. 
Table A2. Net social expenditure in selected countries, 1997

Per cent of GDP at factor costs

\begin{tabular}{|c|c|c|c|c|c|}
\hline & I & II & III & IV & V \\
\hline & $\begin{array}{l}\text { Total gross public } \\
\text { expenditures }{ }^{1}\end{array}$ & $\begin{array}{l}\text { Gross public social } \\
\text { expenditures }\end{array}$ & $\begin{array}{c}\text { Net current public } \\
\text { social } \\
\text { expenditures }\end{array}$ & $\begin{array}{c}\text { Net publicly } \\
\text { mandated social } \\
\text { expenditures }^{3}\end{array}$ & $\begin{array}{c}\text { Net total social } \\
\text { expenditure }\end{array}$ \\
\hline Austria & 49.7 & 28.5 & 23.4 & 23.9 & 24.6 \\
\hline Australia & 33.5 & 18.7 & 17.9 & 18.8 & 21.9 \\
\hline Belgium & 48.8 & 30.4 & 26.3 & 27.5 & 28.5 \\
\hline Canada & 43.9 & 20.7 & 18.7 & 18.7 & 21.8 \\
\hline Czech Republic & 42.4 & 21.7 & 19.3 & 19.3 & 19.3 \\
\hline Denmark $^{5}$ & (2) 54.4 & (1) 35.9 & (3) 26.7 & (4) 26.9 & (4) 27.5 \\
\hline Finland & 51.3 & 33.3 & 24.8 & 24.8 & 25.6 \\
\hline Germany & 46.4 & 29.2 & 27.2 & 27.9 & 28.8 \\
\hline Ireland & 34.0 & 19.6 & 17.1 & 17.1 & 18.4 \\
\hline Italy & 48.5 & 29.4 & 24.1 & 25.2 & 25.3 \\
\hline Japan & 41.7 & 15.7 & 14.8 & 15.3 & 15.7 \\
\hline Netherlands & 44.4 & 27.1 & 20.3 & 20.8 & 24.0 \\
\hline New Zealand & 38.1 & 20.7 & 17.0 & 17.0 & 17.5 \\
\hline Norway & 43.8 & 30.2 & 24.4 & 25.1 & 25.1 \\
\hline Sweden & 58.2 & 35.7 & 28.5 & 28.7 & 30.6 \\
\hline UK & 40.9 & 23.8 & 21.6 & 21.9 & 24.6 \\
\hline United States & 31.4 & 15.8 & 16.4 & 16.8 & 23.4 \\
\hline Country average & 44.2 & 25.6 & 21.7 & 22.1 & 23.7 \\
\hline EU average $^{6}$ & 47.7 & 29.3 & 24.0 & 24.5 & 25.8 \\
\hline
\end{tabular}

Note: Tax breaks for social purposes (TBSPs) are defined as "those reductions, exemptions, deductions or postponement of taxes which: a) perform the same policy function as transfer payments, which, if they existed, would be classified as social expenditures; or $b$ ) are aimed at stimulating private provision of benefits". TBSPs do not include tax advantages favouring married people, as these are considered an integral feature of the general tax system.

1. As a percentage of GDP at market prices.

2. II minus tax claw-back of transfers (including indirect taxes) + TBSPs.

3. III plus net mandatory private social expenditure.

4. IV plus net voluntary private social expenditure.

5. The numbers in the parentheses indicate Denmark's ranking among the 17 countries in the table.

6. Simple average of the $10 \mathrm{EU}$ countries in the table.

Source: Adema (2001). 
ECO/WKP(2002)6

\section{ANNEX II}

\section{ASPECTS OF THE CENTRAL-GOVERNMENT BUDGET PROCESS}

\section{The budget process}

67. Denmark does not have a Budget Act proper. The overall regulations concerning the budget and accounting processes are laid down in the constitution (Table A3) and are supplemented by the authority given to the parliament's finance committee to approve appropriations on behalf of the parliament. The more detailed provisions concerning, for example, budgeting and accounting principles, account structure and spending ministries' preparation of contributions to the budget proposal are specified in executive orders and circulars from the Ministry of Finance $(\mathrm{MoF})$. The same is true for procedures for following up on expenditure developments during the fiscal year as well as for supplying information to the public and the parliament which have mostly emerged more informally. The single most important legal document is the Budget Guidelines (Budgetvejledningen), which is presented to and adopted by the parliament's finance committee and, therefore, has virtually the same status as a law. The most recent overhaul of the Budget Guidelines took place in the 1980s. Over the past decade, a number of less significant adjustments have been made, most recently in 2001.

68. The key elements in the 1980s reform of the Budget Guidelines were the introduction of ministerial expenditure ceilings (MECs) for total outlays within each spending ministry (totalrammer); greater fungibility and decentralisation of the budget process; and the so-called "expanded total balance principle" (Det Udvidede Totalbalanceprincip).

69. The system of ministerial expenditure ceilings aims to combine top-down control over expenditure developments with flexibility within each ministry and its agencies. The preliminary MECs appearing in the budget proposal are initially proposed by the MoF, discussed bilaterally with each spending ministry and eventually determined by the cabinet's economic committee. The MECs comprise separate envelopes for wages, other current expenditures, investments and transfers (including entitlement outlays). The permission to defray entitlement outlays is given in separate laws. Appropriations for such expenditures (typically social transfers) are, therefore, only considered to be estimates. Consequently, the expenditure levels specified in such appropriations can be exceeded. With this exception, once the budget has been passed and the fiscal year has commenced, each ministry must offset overruns in some accounts by savings in others, or apply for a supplementary appropriation. Such a request must — according to a circular from the Prime Minister's office dating back to 1924 - be endorsed by the MoF before its submission to the parliament's finance committee. While the MECs are both efficient and flexible in the internal government decision process, they have less restraining impact in the political negotiations leading up to the adoption of the budget. Thus, the MECs included in the budget proposal may be changed during the political process. 


\section{Table A3. Main features and characteristics of the budget process}

Implementation of the budget adoption

The role and responsibilities of the actors in the budget process

\section{The Constitution}

Submission of the budget bill four month

before the start of the fiscal year, i.e. by the end of August.

No tax can be levied, and no outlays can be defrayed, unless provided for in a Finance

Act passed by the parliament before the

beginning of the fiscal year.

If the reading of the Draft Finance Act is not completed before the start of the fiscal year, a Provisional Appropriation Bill shall be lai before the Parliament.

\section{The Budget Guidelines}

(Budgetvejledningen)

The detailed appropriation provisions are

laid down in the Budget Guidelines, an

executive order from the Ministry of

Finance, which is approved by the

parliament's finance committee in its

capacity of acting on behalf of the parliamen in most budget matters. The Budget

Guidelines specify, for example, the account structure of the budget, the various types of appropriations and the amount of flexibility attached to them.
Ministry/Minister of Finance (MoF)

Eventually update the budget code

(executive orders and circulars).

Set warranted fiscal stance and ministerial expenditure ceilings (MECs).

Bilateral talks with spending ministries on required savings.

Supervise and control spending ministries' budget contributions.

Negotiate with local governments on next year's block grants.

Report continuously to the Cabinet's Economic Committee.

Submit the budget proposal by the end of August at the latest.

\section{Spending ministries/ministers}

Accept MECs or ask for bilateral talks with the $\mathrm{MoF}$

Bilateral talks with the $\mathrm{MoF}$ on required savings.

Draft budget contributions subject to MEC and technical input from the MoF.

\section{Ministry/Minister of Finance \\ Ministry/Minister of Finance} negotiations.

\section{Spending ministries/ministers}

Serve the political negotiations on the issues

under their legal responsibility.

Prepare the legislation required to enact issues under discussion and, if necessary

manage separate political talks at subordinate level.

\section{Parliament's standing finance committe}

Draft the committee's report after the first and the second parliamentary reading.

Pass the "local-government appropriation document" (in June), thereby endorsing next year's block grants to local governments.

\section{Ministry/Minister of Finance}

Surveillance of actual expenditure

developments and provision of information

to the public and the parliament via quarterly

Budget Surveys.

Taking stands on spending ministries'

requests for submissions of appropriation documents for the parliament's finance committee.

Coordinate follow-up on the politica agreements.

Draft and submit the Supplementary Appropriation Act.

\section{Spending ministries/ministers}

Monitor actual expenditure developments in their domain and report to the $\mathrm{MoF}$.

Initiate preparation of appropriation documents for submission to the finance committee whenever this is judged necessary.

Prepare legislation, or other measures, required to implement political agreements in their domain. 
Table A3. Main features and characteristics of the budget process (continued)

\begin{tabular}{|c|c|c|c|}
\hline \multirow[t]{2}{*}{ General legal framework } & Government internal budget preparation & $\begin{array}{l}\text { The parliamentary process: Amendments and } \\
\text { adoption }\end{array}$ & Implementation of the budget \\
\hline & \multicolumn{3}{|c|}{ The role and responsibilities of the actors in the budget process } \\
\hline \multirow{4}{*}{$\begin{array}{l}\text { The State Accountancy Act } \\
\text { Specifies the overall provisions on the state's } \\
\text { accountancy and empowers the MoF to set } \\
\text { the more detailed provisions. }\end{array}$} & Cabinet's Economic Committee & Parliament/opposition parties & \multirow{4}{*}{$\begin{array}{l}\text { Parliament's standing finance committee } \\
\text { Decide on appropriation documents, } \\
\text { including requests for supplementary funds, } \\
\text { on behalf of the parliament. }\end{array}$} \\
\hline & $\begin{array}{l}\text { Decides on strategic elements of the budget } \\
\text { on the basis of recommendations mainly } \\
\text { from the MoF. }\end{array}$ & $\begin{array}{l}\text { Propose adjustments to the government's } \\
\text { budget proposal. }\end{array}$ & \\
\hline & & $\begin{array}{l}\text { Engage in political discussions with the } \\
\text { government. }\end{array}$ & \\
\hline & & $\begin{array}{l}\text { Vote on the budget in its entirety after the } \\
\text { third reading. }\end{array}$ & \\
\hline The Auditor General's Act & & & Parliament \\
\hline $\begin{array}{l}\text { Specifies the competencies and the } \\
\text { responsibilities of the Auditor General. }\end{array}$ & & & $\begin{array}{l}\text { Adopt the Supplementary Appropriation Act, } \\
\text { thereby formally enacting decisions already } \\
\text { taken by the finance committee. }\end{array}$ \\
\hline \multirow{4}{*}{$\begin{array}{l}\text { Characterisation } \\
\text { There is no Budget Act proper, and the } \\
\text { constitution merely sketches a framework for } \\
\text { the budget process. Instead, the detailed } \\
\text { provisions governing the budget process and } \\
\text { the drafting of the budget, etc., are set in } \\
\text { executive orders and circulars from the MoF. } \\
\text { The latter are approved by the parliament's } \\
\text { finance committee, and they broadly have } \\
\text { the same legal effect as a law. While it might } \\
\text { be argued that the reliance on ministerial } \\
\text { regulations risks reducing transparency and } \\
\text { accountability, this should be weighed } \\
\text { against the high degree of flexibility it } \\
\text { allows. }\end{array}$} & Characterisation & \multirow{4}{*}{$\begin{array}{l}\text { Characterisation } \\
\text { Most aspects of the political process between } \\
\text { the launching and the adoption of the budget } \\
\text { is determined by a common understanding } \\
\text { amongst the actors more than by codified } \\
\text { law. In principle, any topic may be brought } \\
\text { up (by all actors) during the negotiations; the } \\
\text { scope of amendments may consequently be } \\
\text { considerable. A party that moves an } \\
\text { amendment would typically (according to } \\
\text { common understanding) have to propose its } \\
\text { financing as well, but no legal constraints } \\
\text { prevent slippage. }\end{array}$} & Characterisation \\
\hline & $\begin{array}{l}\text { The budget preparation is decentralised in } \\
\text { the sense that decisions are taken on the basis } \\
\text { of bilateral talks, while the cabinet does not } \\
\text { take collective decisions on the budget as a } \\
\text { whole. }\end{array}$ & & \multirow{2}{*}{$\begin{array}{l}\text { The execution of the budget is normally in } \\
\text { close compliance with the MECs as the } \\
\text { scope for supplementary appropriations is } \\
\text { limited by the requirement of the MoF's } \\
\text { formal acceptance. Spending ministries have } \\
\text { some flexibility in the use of their budgets, } \\
\text { for example in terms of keeping unforeseen } \\
\text { revenue and carrying forward unused funds } \\
\text { forward. }\end{array}$} \\
\hline & $\begin{array}{l}\text { The MoF holds a dominant strategic position } \\
\text { by setting MECs and the fiscal-stance target, } \\
\text { thereby ensuring a top-down approach. }\end{array}$ & & \\
\hline & & & $\begin{array}{l}\text { Appropriations can also be, within rather } \\
\text { narrow limits, redistributed for other } \\
\text { purposes than those specified in the budget. }\end{array}$ \\
\hline
\end{tabular}

Source: OECD 
70. The 1980s budget reform also aimed at facilitating greater fungibility and decentralisation. For example, greater flexibility for individual ministries and agencies to reallocate funds within their envelope was introduced, and the scope for carrying forward unused appropriations to later years was increased. Since the 1980s, further adjustments have been made to increase flexibility. Thus, carry-over of funds is now possible for all current expenditure, investments and some transfer programmes. In addition, the scope of net budgeting has been increased to include all current expenditure, thereby allowing higher commercial revenues to finance higher spending.

71. Finally, reflecting the newly established framework for budget co-operation between the central government and counties and municipalities, the so-called "expanded total balance principle" was introduced. It implies that financial compensation to local governments for extra expenditures originating from new, or changed, legislation must be made from within individual ministries' expenditure ceilings as well.

72. In its technical design, the budget may be characterised by the following features:

- Cash budgeting and accounting have been standard practice in the Danish budget system since the 1950s. However, budgeting for the net present value of government commitments that go beyond the current fiscal year (for example, interest subsidies to social housing) were introduced in 2001. In addition, a MoF working group recently recommended that accrual accounting should be implemented in central-government balance sheets as from 2004 (Finansministeriet, 2000d).

- Some elements of accrual budgeting are already in place. Central government property has, partly, been transferred to central units, which in turn rent out office space to government institutions. Also, appropriations for higher education and vocational training are based on activity levels (unit costs).

- Multi-year budgeting is relatively weak. Appropriation calculations are included for three budget-forecast years subsequent to the fiscal year, but this framework is not fully integrated with the medium-term economic projections underlying the formulation of the overall economic strategy.

- Since 1990, all benefit levels in the transfer system have been linked to private-sector wage developments (with a lag of two years). Changes in the average private-sector wage level that arise from compositional effects - for example the decreasing share of unskilled workers are not compensated. Otherwise, there is no mechanism in the indexing scheme itself that causes the transfer-to-GDP ratio to either increase or decrease over time. The percentage annual increase in nominal benefit levels is announced routinely by the MoF in an executive order and involves no political decision-taking.

\section{Public investment policies}

73. Government investment policies have changed in several respects in the recent past. In particular, the responsibility for big infrastructure projects is increasingly being assigned to typically fully state-owned companies. Examples include the Danish natural gas grid, bridge and tunnel projects and the current metro project in Copenhagen. The responsibilities of the established companies typically comprise financing, building and operating the projects. Funds are raised in the capital markets against a state guarantee, while user charges are intended to facilitate the subsequent amortisation of the loans. In addition, several capital-intensive government activities, including postal services and railways, have been separated out from the budget itself and converted into independent companies. As the services from such investment are eventually mainly user-financed, the investment expenditure itself appears as business 
rather than general-government investment in the national accounts. Information on public-sector companies' investments is not available before 1993, but in the period since then, it has risen some 20 per cent in constant prices. The public-enterprise sector accounted for 13 per cent of total gross fixed investment in 1998, while the general government's share was 8 per cent (Figure A2). Companies owned by the central government account for the dominant part of the investments by public-sector enterprises. In contrast, local-government investment activity remains largely tax-financed, due, in part, to legal restrictions on their borrowing powers.

\section{Figure A2. Private and public gross fixed investments Per cent}

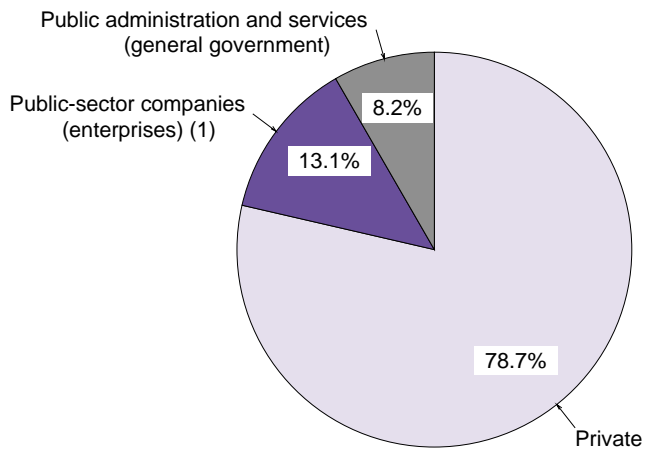

1. Public-sector companies' investments figure in the national accounts as investments in the enterprise sector, rather than in general government.

Source: Regeringen (2001b).

74. Inspired by the ongoing expansion of public-private partnerships (PPP) in the United Kingdom, a recent government report (Regeringen, 2001) recommended analysing further the advantages and disadvantages of more direct private-sector involvement in investment activity, including the subsequent ownership and responsibility for maintenance activity. Indeed, private ownership might potentially have a number of advantages including a clearer governance structure, shifting the risk assessment to the market and higher productivity in the provision of services. In addition, past and recent experience with projects that have been undertaken by publicly owned companies are mixed, at best, as delays and cost overruns have been frequent. The arguments for allowing and encouraging (partial) private ownership - where appropriate - are quite similar to those underlying the policy in the recent years to privatise state-owned enterprises.

75. As in other countries, general-government (tax-financed) investment has declined steadily from some $4 \frac{1}{2}$ per cent of GDP in the early 1970 s to $13 / 4$ per cent in recent years. Investment expenditure funded by the central government is treated separately in the budget process. Following a new procedure introduced in 1999, spending ministries are not allocated funds for investment except to continue projects already started. New projects are prioritised centrally within a budget envelope by the government's economic committee amongst proposals submitted by individual ministries. Submissions must provide certain background information, ranging from proper cost-benefit analysis for major infrastructure projects to considerations for existing capacity and future operational costs for cultural institutions. Cost-benefit analyses must comply with MoF guidelines (Finansministeriet, 1999b), which, amongst other things, recommend using a real rate of return of 6 to 7 per cent. In contrast, local governments' investment decisions (covering three-quarters of general-government investment) are subject to only very few regulatory constraints. For example, there exist no requirements to undertake cost-benefit analysis. 


\section{ANNEX III}

\section{FINANCING LOCAL GOVERNMENTS}

\section{Extensive devolution of responsibilities to local governments}

76. The most important functions carried out at the county level are hospital services, health insurance, upper secondary education, care for disabled people and regional public transport. The municipalities' tasks comprise the provision of services such as primary and lower-secondary education, childcare, elderly care and labour-market programmes for the unemployed without benefit entitlement (Table A4). In addition, the extent of local-government involvement in the social-security schemes is unique amongst the OECD countries; most importantly, the municipalities are responsible for assessing the eligibility of applicants for early retirement pension, which is the second-largest social-security scheme after old-age pension.

Table A4. The responsibilities of counties and municipalities

\begin{tabular}{ll}
\hline Municipalities & Counties \\
\hline & \\
Services & Services \\
Primary and lower secondary education & Hospitals \\
Childcare & Health insurance \\
Elderly care & Upper secondary education \\
Libraries, local sports facilities & Care of mentally and physically disabled people \\
Public utilities & Certain cultural activities \\
Environmental supervision & Regional public transport \\
Emergency services & Regional physical planning \\
Labour-market programmes for cash-benefit recipients & \\
Integration of refugees & \\
& \\
Social transfers & \\
Assessment of eligibility for: & \\
Early retirement (disability) pension & \\
Cash benefit & \\
Rehabilitation benefit & \\
Wage subsidies to people with reduced working capacity & \\
Follow-up measures vis-à-vis sickness-benefit recipients &
\end{tabular}

Source: OECD; Ministry of the Interior (1999). 
77. The 1970 municipal reform resulted in a local-government structure with 14 counties and 275 municipalities, a structure that has since remained almost unchanged. ${ }^{1}$ The decentralisation process was made possible by this reform, but it has gone much further than what was envisaged at that time (Indenrigsministeriet, 1998). Decentralisation has also continued far beyond what could reasonably be labelled as the provision of "local public goods", and thereby beyond the arguments of the classical theory of fiscal federalism (Oates, 1990 and Lotz, 1998). Among the larger spending areas only tertiary education and labour-market policies are still managed at the national level along with central administration, defence and the judicial system. ${ }^{2}$

\section{Local governments' revenue structure}

78. Taxes account for 58 per cent of local governments' total revenue. In addition to income taxes local-government taxes also comprise land and property taxes:

- The income tax base is set by the central government. The average tax rate (the total of municipal and county rates) has risen from less than 20 per cent in the early 1970 s to 32 per cent in 2001 .

- Both counties and municipalities levy land tax at rates that are allowed to vary between 0.6 and 2.4 per cent of the land value. Around one-quarter of the municipalities have set their rate at - or near - the minimum level, and very few apply the highest rate possible. The average land-tax rate was 1.6 per cent in 2001 and has risen much less over the recent past than have income-tax rates.

- In addition to the land tax, the former imputed rents tax was converted into a municipal property tax as part of the 1998 tax reform. However, the property-tax rate is uniform across municipalities and is fixed by the central government.

79. The second largest revenue component is sales of goods and services at 23 per cent (Figure A3). This latter includes primarily households' and companies' payments for public utilities' services but also user charges for childcare and certain auxiliary services. Block grants from the central government, which are not tied to any specific purpose, amount to some 11 per cent of total revenues. These grants are distributed to local governments according to their tax bases and do not, therefore, imply any redistribution. Finally, reimbursements amount to 8 per cent of revenues (excluding old-age pension, which is fully reimbursed by the central government). Reimbursements apply primarily to social transfer schemes such as early retirement (disability) pension, cash benefit and sickness benefit. Municipalities'

1. The only change is the imminent amalgamation of the five municipalities of the island of Bornholm into one administrative unit, which was decided upon in a referendum in May 2001. Before 1970, Denmark was divided into 86 boroughs, and around 1300 parishes within 25 counties. In many areas, however, the urban expansion had extended across the boundaries of neighbouring parishes, and many parishes were too small to near the costs of professional administration, let alone managing basic services like primary education or elderly care.

2. In the case of active labour-market policies, the social partners have been allowed greater influence on policies than users in other areas. For example, the unemployment insurance funds are managed by the social partners, who also hold considerable discretion over decisions regarding the content of adult-education programmes. Even the appeal system is different from that in other sectors. Thus, for social services and in the health sector, the highest appeal body is a purely state authority whose decisions may be contested in the ordinary judicial system. For labour-market policies, the highest appeal instance is indeed formally independent, but the social partners appoint the majority of the members of its board, and its decisions cannot be appealed. 
outlays under these schemes are partly compensated directly by the central government at rates that vary between 35 and 50 per cent. The differences between total outlays and aggregate reimbursements are paid by the central government according to the same distribution as the block grants.

Figure A3. Local governments' revenue structure, 2000 Per cent

A. Land and income tax rates

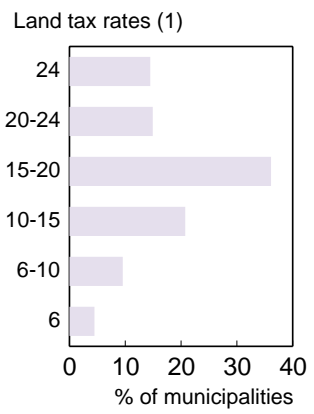

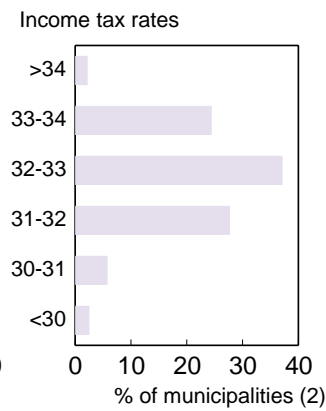

B. Revenue structure

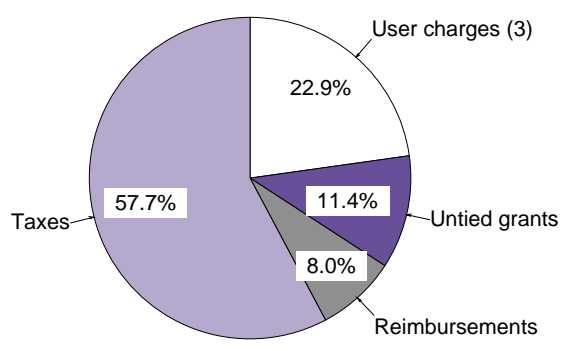

1. Per thousand of land values.

2. If measured as a percentage of all inhabitants, the distribution of income tax rates is more concentrated in the 32 to 33 per cent range.

3. This includes primarily payments for public utilities services but also user charges for child care and certain auxiliary services.

Source: Statistics Denmark; Ministry of the Interior (1999).

80. Redistribution via equalisation is essential, given the combination of extensive taxing powers, non-redistributing central-government grants and the devolution of non-local-goods services to local governments (Lotz, 2001). As only per-inhabitant differences are equalised, the schemes do not reduce individual municipalities' incentives to increase tax bases by attracting new residents. The equalisation schemes aim to strike a balance between their main purpose of making roughly equal standards possible at equal tax rates and providing reasonable incentives for individual local authorities to strengthen tax bases and operate efficiently. While they imply considerable narrowing of tax-rate dispersion, differences are far from being eliminated altogether (Figure A4, Panel B). Moreover, the Danish schemes imply less redistribution than those in some other countries, for example, Norway, Finland, Sweden and Australia; in the last two, equalisation is approximately 100 per cent on both the revenue and the expenditure side. The schemes appear to work without too much tension, although some dissatisfaction is frequently voiced from both the largest contributors and the biggest beneficiaries. Nonetheless, the design of the current equalisation system has some peculiarities. In particular, the range of different equalisation percentages and the criteria upon which they hinge (see box below) are somewhat arbitrary, and, in particular, it is not obvious why equalisation in the Copenhagen metropolitan area should be greater than elsewhere (Table A5). Furthermore, the more generous grants scheme to poor municipalities (with per capita tax bases below 90 per cent of the national average) implies that these have very little incentive to strengthen their tax base. 
ECO/WKP(2002)6

Figure A4. Effects of inter-municipal equalisation

2000
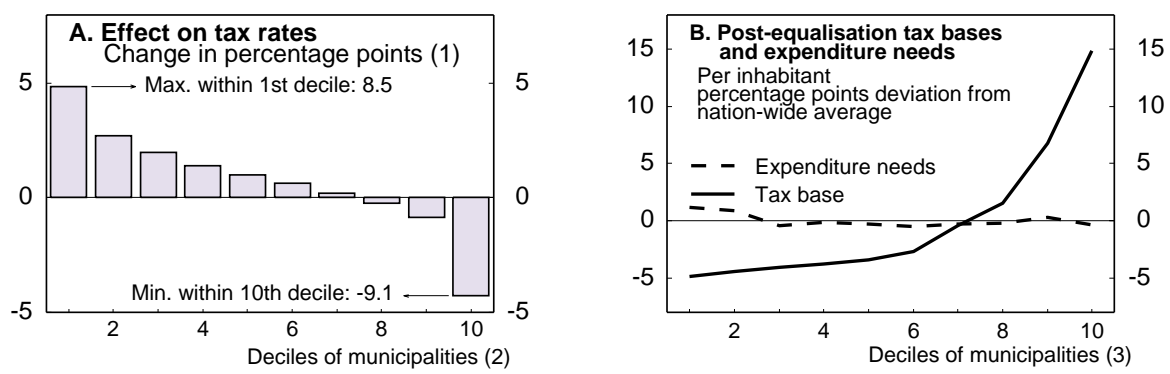

1. Increase in the tax rate that would be necessary to maintain current spending if equalisation were absent and central government grants were distributed according to the number of inhabitants instead of taxable perinhabitant income. Median municipality within each decile.

2. Ranked in descending order according to the tax-rate effect.

3. Increasing according to per-inhabitant taxable income.

Source: Ministry of the Interior; Lotz (2001).

\section{Inter-municipal equalisation}

Equalisation takes place on both the revenue and the expenditure sides of local governments' budgets, and it applies to both municipalities and counties. The equalisation base on the revenue side is the sum of the income tax base and a share of taxable land values, all measured on a per-inhabitant basis. The equalisation for expenditure needs is more complicated; it is based on a composite index, which takes three elements into consideration. The first is an "estimate" of the minimum amount required to operate a reasonable professional administration in a small municipality ( $\mathrm{DKr} 71 / 2$ million). The second is the age profile in each local authority, thereby taking account of demographic expenditure pressures. Finally, a number of indicators of the social structure (for example the number of children of single parents and the number of rental dwellings) enter the calculation of the composite index. In the selection of these indicators of expenditure needs, the intent has been to ensure that they are "exogenous" in the sense that individual local authorities cannot manipulate the outcome, at least not in the short term.

The county schemes equalise 80 per cent of the difference from the national averages for tax bases as well as expenditure needs (Table A5). The national municipal scheme equalises only 45 per cent of the deviations from average tax bases and expenditure needs. However, an additional 40 per cent of the differences is equalised within the greater Copenhagen area, and there is a separate scheme that compensates "poor" municipalities (defined as those with a tax base per inhabitant of less than 90 per cent of the national average) for an additional 40 per cent of the gap. In sum, the equalisation is generally greater at the county than at the municipal level and greater in the Copenhagen metropolitan area than in the rest of the country. 
Table A5. Inter-municipal equalisation schemes ${ }^{1}$

\begin{tabular}{lll|ll}
\hline & \multicolumn{2}{c|}{ Tax base equalisation $^{2}$} & \multicolumn{2}{c}{ Equalisation of expenditure needs $^{3}$} \\
\cline { 2 - 4 } & Counties & Municipalities & Counties & Municipalities \\
\cline { 2 - 4 } National scheme & 80 per cent & 45 per cent & 80 per cent & 45 per cent \\
$\begin{array}{l}\text { Copenhagen area } \\
\text { scheme }\end{array}$ & - & $\begin{array}{l}40 \text { per cent on top of } \\
\text { the national scheme }\end{array}$ & - & $\begin{array}{l}\text { 40 per cent on top of } \\
\text { the national scheme }\end{array}$ \\
$\begin{array}{l}\text { Grants to poor } \\
\text { municipalities }\end{array}$ & - & $\begin{array}{l}40 \text { per cent on top of } \\
\text { the national scheme }\end{array}$ & - & - \\
\hline
\end{tabular}

Note: The percentages refer to the proportion of the difference between an individual local government's tax base or expenditure needs and the average, which is equalised.

1. The Ministry of the Interior operates a number of other minor equalisation schemes in addition to those reported here. For example, separate schemes are in place for sharing costs of refugees or supporting municipalities on small islands.

2. The tax base comprises the income tax base plus 6.5 per cent of taxable land values. Municipalities also receive a share of corporate tax revenue, but the latter is not equalised.

3. Expenditure needs are proxied by a composite index comprising three basic elements: $i$ ) a basic amount of DKr 7.5 billion; ii) a number of demographic characteristics; and iii) a number of social criteria.

4. Municipalities with a tax base per inhabitant that is at least 10 per cent below the national average get an additional 40 per cent of the difference equalised, i.e. on the top of the national scheme. This grant, for which close to 100 municipalities qualified in 2000 , is financed collectively via the block grant scheme.

Source: Ministry of the Interior (1999). 
ECO/WKP(2002)6

\section{ANNEX IV}

\section{POLICIES ON USER CHARGES IN SELECTED AREAS}

8. As argued in the main text user charges are not, at present, applied consistently. First, while distributional concerns are allegedly important in shaping policies, it is not always obvious that these are more compelling for services provided free of charge than for others on which user charges are levied. Labour-market training for employed, for example, is generally free, while dental care is subject to considerable user co-payment. Second, where charges exist, they do not appear well aligned with the likely price sensitivity of demand. The optimal level of user charges might tentatively be defined as that which "best" balances the trade-off between unwarranted distributional effects and beneficial impacts in curbing (excessive) demand relative to free provision. ${ }^{1}$ Defining the optimal charge is obviously much easier than determining it in practice, if only because information on the price elasticities is limited. A general guideline is, nevertheless, that charges should be linked directly to individuals' actual consumption, ${ }^{2}$ in contrast with fixed fees (earmarked taxes). However, distributional concerns could often provide an argument for a cap on user charges, in particular if the price sensitivity declines with increasing demand, as might often be the case with health services, for example.

9. This annex provides some information on current policies in the areas of childcare and pharmaceuticals, where user co-payment schemes exist. In addition, it outlines some arguments for and against broadening the application of user charges, even if only of modest size, to a range of other services currently provided free.

\section{Childcare}

10. For childcare, municipalities are entitled to levy user charges subject to limits set by the central government. The statutory co-payment percentages vary between 30 and 35 per cent of the full costs, while effective co-payments are around 20 per cent of full costs. The introduction of the "brothers-and-sisters" discount early in the 1990s implied a significant reduction of effective user charges. The discount, which is compulsory for the municipalities, implies that parents pay normal tariff for one child, while for all subsequent children, they enjoy a 50 per cent discount. For example, parents with one child under three years of age and one between three and six years of age will typically pay half charge for the latter child, which in an average municipality would be some DKr 750 per month (the equivalent of $€ 100$ ) for a full-time place.

1. If the overriding objectives were to ensure economic efficiency, marginal cost pricing would theoretically provide the "best" user charges. If fees are set below marginal costs, and demand is price sensitive, individuals will consume more than they otherwise would.

2. Insurance companies use co-payments in precisely the same way to limit "moral hazard". 
11. For children aged three to five years (in kindergarten) the coverage ratio has increased from below 80 per cent in 1991 to almost 95 per cent in 2001 . Over the same period, half-time day-care places ${ }^{3}$ have largely been abolished and converted into full-time places. In part, this standardisation is likely to result from a demand response to the "brothers-and-sisters" discount. ${ }^{4}$ Thus, if only the marginal price is low enough parents may demand full-time day care even if their "objective need" is well below this and despite children's actual attendance (i.e. the number of hours per week in day-care) being well below full time on average. Considering the extra flexibility full-time places provide, the marginal price is indeed quite low, in particular if the "brothers-and-sisters" discount applies; in the last case parents' monthly payment would typically only be DKr 300 higher for a full-time place relative to a half-time place. The general point is that families' true demand for childcare is likely to vary considerably according to working time and working patterns, and the availability of help from relatives, etc. This does not conform to the observed standardised supply structure.

12. Experience from Sweden over the past decade provides an interesting contrast to the standardisation observed in Denmark. The structure of the Swedish childcare sector around 1990 showed considerable resemblance with its Danish counterpart both in having a limited degree of diversity in the types of places provided (per hour, half-time, full-time, etc.) and in the level of parents' payment. However, over the course of the 1990s the sector evolved very differently in the two countries. Unlike in Denmark, user charges were not reduced in Sweden and municipalities have not been bound by legal constraints in setting the level of charges. Against this backdrop, it is interesting to observe that the supply structure became much more diversified during the course of the 1990s and user charges became more closely linked to the actual attendance. In 1993, 60 per cent of the municipalities in Sweden had no or only a weak link between the size charges and the number of hours of attendance. In that year, one-fifth of the municipalities had four different rates or more. In 1999, the equivalent figure was 67 per cent, and 18 per cent of the municipalities had moved to charging on a per-hour basis (Skolverket, 1999).

13. The design of charges in Denmark appears inappropriate from an economic point of view, as they relate to average rather than marginal consumption. There is virtually no relation between the individual child's actual time spent in day care and the parents payment, partly because full-time places are the only type of service on offer. Thus, the present system neither encourages nor enables parents with reduced need $^{5}$ for care hours to align demand with their actual need. Redesigning user charges by relating them to marginal consumption, i.e. moving to charges that vary with actual attendance could facilitate a reduction in (excessive) demand without compromising labour supply. Some caution is necessary, though, as excessive time dependence might add to effective marginal tax rates, thereby discouraging high or increasing working hours.

3. Opening hours in half- and full-time places may vary somewhat, but typical opening hours would be daily between $7 \mathrm{~h} 00$ and $13 \mathrm{~h} 30$ in half-time places and between $6 \mathrm{~h} 30$ and $17 \mathrm{~h} 30$ in full-time places.

4. Empirical findings suggest that the demand for out-of-home childcare is quite responsive to the price when demand is not rationed. For example, Hofferth and Wissoker, (1991) estimate a price elasticity of -3 to -4 on American data, and Gustafsson and Stafford (1991) find an elasticity of -2.7 on Swedish data between the joint decision to work and use public childcare one the one hand and parents' payment for childcare on the other.

5. Such as part-time and shift workers, parents on leave, temporarily non-employed or parents with non-working relatives living nearby. 


\section{Pharmaceuticals}

14. Demand for pharmaceuticals is normally considered relatively price elastic, ${ }^{6}$ at least for smallscale users, indicating that private co-payment could be effectual in curbing public outlays. However, discouraging excessive consumption should be reconciled with safeguarding those in need of expensive drugs and long-term treatment. The level of private co-payment in Denmark is a little above the OECD average, and per capita consumption is somewhat lower (Jacobzone, 2000). The latter reflects cautious prescription habits and the success of the public sector in using its monopsony power to impose the use of generics and keep a tight rein on prices through reference pricing. Nonetheless, public expenditure has increased rapidly over the past decade. The subsidy scheme in place during under this period may have given insufficient economic incentive for households to restrain consumption, as the co-payment was fully proportional to the final price.

15. The "stop-loss" type of subsidy scheme that came into force in March 2000 aimed at improving the system on this count. It effectively increased payment for consumption under a certain threshold, while providing better coverage for high users. Unlike its predecessor, the current scheme does not embody any differentiation of various types of drugs. Instead, consumption below DKr 500 per year is fully paid by the consumer, while 85 per cent of consumption above $\mathrm{DKr} 2800$ is reimbursed; intermediate consumption is partially reimbursed at lower percentages. ${ }^{7}$ It is still too early to assess the impact of the new system and the threshold in particular. However, when a similar system was in place in 1990 and 1991, the trend increase in public reimbursements reversed to a significant decline. At that time, the "stop-loss" scheme was abolished less than two years after its introduction, as its administration proved too cumbersome. This drawback has been avoided in the new system under which all purchases are instantaneously stored electronically in a central register.

\section{Broadening user charges to other services}

\section{Elderly care}

16. Public spending for elderly care is higher in Denmark than elsewhere, while informal care providers play a less important role. In large part this is attributable to within-family resources being limited by factors such as high labour-force participation rates and the fact that a higher proportion of the elderly live alone. While broad, publicly financed provision of elderly care therefore seems natural, the absence of any user charges is nevertheless remarkable. Following the abolition of user charges in 1989, Denmark stands out in an international comparison by providing elderly care, i.e. personal care and practical home help free (Rostgaard and Fridberg, 1998; Jacobzone, 1999). As part of the agreement with the National Association of Local Governments in 1998, the previous government committed itself to introducing income-dependent user charges for practical home help. However, it subsequently retreated from this commitment due to both political and administrative difficulties. As the demand for home care is likely to quite price sensitive excessive demand and spending pressures could probably be better contained if even modest user charges were introduced.

6. Jacobzone (2000) refers to results from the Rand Health Insurance Experiment, considered the most comprehensive study available on price effects on demand for pharmaceuticals. The study found that co-payments of 25 per cent reduce demand by a quarter, thereby suggesting a price elasticity of -1 .

7. These are 2000 levels which are adjusted annually according to private-sector wage developments. For the chronically ill, the annual payment is capped at DKr 3600. 


\section{Health care}

17. Primary health care is free and fully tax financed. Resistance against user charges is profound, not only amongst policy makers; in a recent analysis of the Danish health-care sector the Economic Council concluded, mainly on the ground of the implied distributional effects, that user charges are inappropriate in this area (Det økonomiske Råd, 2000). Consumption of primary health services is indeed higher for people in the lowest deciles of the income distribution than for those with high incomes, in particular because pensioners typically have above-average consumption and below-average incomes. Thus, introducing user charges and cutting taxes would increase inequality, but could be alleviated to some extent by exempting pensioners or making charges subject to a ceiling. Nevertheless, many countries do apply user charges for primary health care. ${ }^{8}$ This includes the other Scandinavian countries, where equity objectives are probably as strong as in Denmark. ${ }^{9}$ The fact that private co-payment for these services has a long history in Sweden and Norway but are considered unthinkable in Denmark illustrates the ambiguity of the distribution argument.

18. Moreover, unlimited user charges (i.e. without a ceiling) exist for dental care, and the effective private co-payment rate has increased over the past 15 years from 25 to 40 per cent. Although the new subsidy scheme for pharmaceuticals described above has now reduced co-payments for high users, unlimited charges have also been in place in this area until recently, which is somewhat surprising, given the emphasis on equity objectives in other areas.

19. A number of studies (for example, Pedersen et al. (1995) suggest that user payment for visits to general practitioners, subject to an annual ceiling of some DKr $1000(€ 135)$ might reduce public spending by some 25 per cent - one-quarter of which is attributable to the demand response and the remaining part due to the revenue from the user charge itself. These savings are relatively modest in absolute terms and should be balanced against other considerations such as the risk of deterring preventive cares. In addition, it should be kept in mind that the Danish health care sector is relatively cheap exactly because of the gatekeeper function served by the general practitioners.

\section{Tertiary education}

81. While the private return on human capital investment is reduced by the compressed wage structure and the high progressivity of the tax system, the financial terms of acquiring tertiary education are generous. There are no tuition fees and the effective, private co-payment rate is very low by international standards (see Table 18). In addition, student grants are more generous than elsewhere. Introducing tuition fees could probably improve outcomes in several respects. As discussed in the previous Survey, the amount of excessive time spent in the education system is considerable, and, on average, Danish students graduate at a higher age than in almost any other OECD country. This causes significant fiscal costs because of the implied extra education spending and the tax revenue foregone because of the postponed entry into the work force. Including some element of payment would strengthen incentives to complete studies on time. The fact that the return on human capital investment is primarily private (despite the aforementioned effects) is an argument for such tuition fees being substantial. However, if this is deemed unacceptable because of the implied distributional effects, even linking modest charges to examinations (thereby putting a price on not attending planned exams or re-doing exams to improve previously obtained results) might in itself encourage a faster pass-through.

8. Manning et al. (1987) find that the demand response from introducing user charges is bigger for primary than for secondary care and that it weakens the greater is the share of private co-financing.

9. Another group of counties, including Canada, Germany, the Netherlands (public), Spain and the United Kingdom follow the Danish example of providing primary health care free. 


\section{ECONOMICS DEPARTMENT \\ WORKING PAPERS}

319. Options for Reforming the Finnish Tax System (February) Isabelle Joumard and Wim Suyker

318. Product Market Regulation and Wage Premia in Europe and North America: An Empirical Investigation (January 2002) Sébastien Jean and Giuseppe Nicoletti

317. Competition, Innovation and Productivity Growth: A Review of Theory and Evidence (January 2002) Sanghoon Ahn

316. Labour Market Institutions, Product Market Regulation, and Innovation : Cross Country Evidence (January 2002) Andrea Bassanini and Ekkehard Ernst

315. Ongoing Changes in the Business Cycle - Evidence and Causes (January 2002) Thomas Dalsgaard, Jorgen Elmeskov and Cyn-Young Park

314. Comment encourager une croissance ecologiquement durable en France? (December 2001) Ann Vourc'h et Patrick Lenain

313. Increasing Efficiency and Reducing Complexity in the Tax System in the United States (December 2001) Richard Herd and Chiara Bronchi

312. Product and Labour Markets Interactions in OECD Countries (December 2001) Giuseppe Nicoletti, Andrea Bassanini, Ekkehard Ernst, Sébastien Jean, Paulo Santiago and Paul Swaim

311. Modelling Import Responsiveness for OECD Manufactures Trade (October 2001) Mara Meacci and David Turner

310. Trade Linkages and the Trade Matrices in the OECD Interlink Model (October 2001) Laurence Le Fouler, Wim Suyker and Dave Turner

309. Encouraging Environmentally Sustainable Growth in Australia (October 2001) Ann Vourc'h and Robert Price

308. Financial Market Liberalisation, Wealth and Consumption (September 2001) Laurence Boone, Nathalie Girouard and Isabelle Wanner

307. The Economic Integration of Germany's New Länder (September 2001) Eckhard Wurzel

306. Standard Shocks in the OECD Interlink Model (September 2001) Thomas Dalsgaard, Christophe André and Pete Richardson

305. Fiscal Implications of Ageing: Projections of Age-related Spending (September 2001) Thai Thanh Dang, Pablo Antolin and Howard Oxley

304. The Width of the Intra-European Economic Borders (August 2001) Alain de Serres, Peter Hoeller and Christine de la Maisonneuve

303. Surveillance of Tax Policies: A Synthesis of Findings in Economic Surveys (July 2001) Paul van den Noord and Christopher Heady 


\section{ECO/WKP(2002)6}

302. Reforming the Tax System in Portugal (July 2001) Chiara Bronchi, José C. Gomes-Santos

301. Tax Systems in European Union Countries (June 2001) Isabelle Joumard

300. Encouraging Environmentally Sustainable Growth in Belgium (June 2001) Paul O’Brien, David Carey, Jens Høj, Andreas Woergoetter

299. Encouraging Environmentally Sustainable Growth in Poland (June 2001) Grzegorz Peszko, Patrick Lenain

298. Tracking the Euro (June 2001) Vincent Koen, Laurence Boone, Alain de Serres, Nicola Fuchs

297. Firm Dynamics and Productivity Growth: A Review of Micro-evidence from OECD Countries (June 2001) Sanghoon Ahn

296. How should Norway Respond to Ageing? (May 2001) Pablo Antolín and Wim Suyker

295. How will Ageing Affect Finland?

(May 2001) Pablo Antolín, Howard Oxley and Wim Suyker

294. Sectoral Regulatory Reforms in Italy: Framework and Implications (May 2001) Alessandro Goglio

293. Encouraging Environmentally Sustainable Growth: Experience in OECD Countries (May 2001) Paul O'Brien and Ann Vourc'h

292. Increasing Simplicity, Neutrality and Sustainability: A Basis for Tax Reform in Iceland (May 2001) Richard Herd and Thorsteinn Thorgeirsson

291. Options for Reforming the Tax System in Greece (April 2001) Chiara Bronchi

290. Encouraging Environmentally Sustainable Growth in Canada (March 2001) Ann Vourc'h

289. Encouraging Environmentally Sustainable Growth in Sweden (March 2001) Deborah Roseveare

288. Public Spending in Mexico: How to Enhance its Effectiveness (March 2001) Bénédicte Larre and Marcos Bonturi

287. Regulation in Services: OECD Patterns and Economic Implications (February 2001) Giuseppe Nicoletti

286. A Small Global Forecasting Model (February 2001) David Rae and David Turner

285. Managing Public Expenditure: Some Emerging Policy Issues and a Framework for Analysis (February 2001) Paul Atkinson and Paul van den Noord 